Prepared in cooperation with the Hannahville Indian Community

\title{
Geophysical-Log and Hydraulic-Test Analyses of Groundwater-Production Wells at the Hannahville Indian Community, Menominee County, Michigan
}

Scientific Investigations Report 2013-5172 



\section{Geophysical-Log and Hydraulic-Test Analyses of Groundwater-Production Wells at the Hannahville Indian Community, Menominee County, Michigan}

By E. Randall Bayless, J. Alton Anderson, David C. Lampe, and John H. Williams

Prepared in cooperation with the Hannahville Indian Community

Scientific Investigations Report 2013-5172 


\title{
U.S. Department of the Interior SALLY JEWELL, Secretary
}

\section{U.S. Geological Survey Suzette M. Kimball, Acting Director}

\author{
U.S. Geological Survey, Reston, Virginia: 2013
}

For more information on the USGS - the Federal source for science about the Earth, its natural and living resources, natural hazards, and the environment, visit http://www.usgs.gov or call 1-888-ASK-USGS.

For an overview of USGS information products, including maps, imagery, and publications, visit http://www.usgs.gov/pubprod

To order this and other USGS information products, visit http://store.usgs.gov

Any use of trade, firm, or product names is for descriptive purposes only and does not imply endorsement by the U.S. Government.

Although this information product, for the most part, is in the public domain, it also may contain copyrighted materials as noted in the text. Permission to reproduce copyrighted items must be secured from the copyright owner.

Suggested citation:

Bayless, E.R., Anderson, J.A., Lampe, D.C., and Williams, J.H., 2013, Geophysical-log and hydraulic-test analyses of groundwater-production wells at the Hannahville Indian Community, Menominee County, Michigan: U.S. Geological Survey Scientific Investigations Report 2013-5172, 29 p., http://dx.doi.org/10.3133/sir20135172. 


\section{Contents}

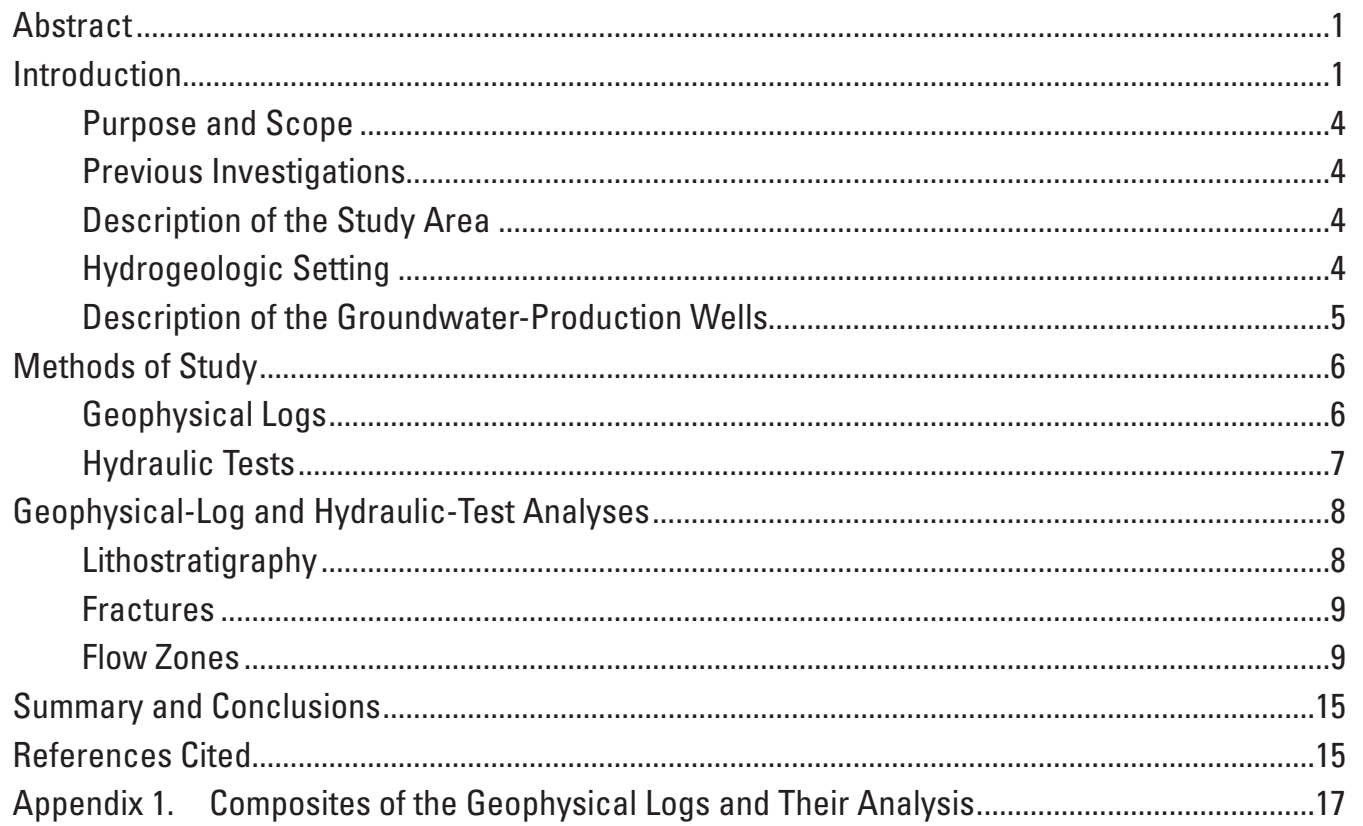

\section{Figures}

1. Map showing location of the Hannahville Indian Community, in the Upper Peninsula of Michigan.

2. Map showing location of the Cambrian-Ordovician aquifer system, and the study area in the northern Midwest of the United States

3. Schematic section of selected geophysical logs for groundwater-production wells Casino 3, Casino 5, Golf Shack, Community 1, and Community 2 showing lithostratigraphy, natural gamma, and flow zones. Logs terminate at the bottom of the well, not the base of the formation. Approximately 3 miles separate the northernmost and southernmost wells

4. Images of optical televiewer (OTV) and acoustic televiewer (ATV) logs of the bottom 17 feet of the Casino 5 well showing vuggy beds in the lower carbonate rock unit.

5. Plot showing measured change in flow in the Casino 3 well at 271 feet below land surface while the Casino 5 well is pumped at 80 gallons per minute, and model analysis of cross-flow data by use of the technique of Paillet (1998).

\section{Tables}

1. Generalized stratigraphy in the vicinity of the Hannahville Indian Community, Menominee County, Michigan.

2. Land-surface elevation and construction for five groundwater-production wells, Hannahville Indian Community, Menominee County, Michigan

3. Summary of distribution and hydraulic properties of the flow zones penetrated by each of five groundwater-production wells at Hannahville Indian Community, Menominee County, Michigan. 


\section{Conversion Factors, Datums, and Abbreviations}

Inch/Pound to SI

\begin{tabular}{|c|c|c|}
\hline Multiply & By & To obtain \\
\hline \multicolumn{3}{|c|}{ Length } \\
\hline inch (in.) & 2.54 & centimeter $(\mathrm{cm})$ \\
\hline inch (in.) & 25.4 & millimeter $(\mathrm{mm})$ \\
\hline foot $(\mathrm{ft})$ & 0.3048 & meter $(\mathrm{m})$ \\
\hline mile (mi) & 1.609 & kilometer $(\mathrm{km})$ \\
\hline \multicolumn{3}{|c|}{ Area } \\
\hline acre & 4,047 & square meter $\left(\mathrm{m}^{2}\right)$ \\
\hline acre & 0.4047 & hectare (ha) \\
\hline square mile $\left(\mathrm{mi}^{2}\right)$ & 2.590 & square kilometer $\left(\mathrm{km}^{2}\right)$ \\
\hline \multicolumn{3}{|c|}{ Flow rate } \\
\hline foot per day (ft/d) & 0.3048 & meter per day $(\mathrm{m} / \mathrm{d})$ \\
\hline gallon per minute (gal/min) & 0.06309 & liter per second $(\mathrm{L} / \mathrm{s})$ \\
\hline gallon per day (gal/d) & 0.003785 & cubic meter per day $\left(\mathrm{m}^{3} / \mathrm{d}\right)$ \\
\hline inch per year (in/yr) & 25.4 & millimeter per year (mm/yr) \\
\hline \multicolumn{3}{|c|}{ Hydraulic conductivity } \\
\hline foot per day (ft/d) & 0.3048 & meter per day (m/day) \\
\hline foot per day (ft/d) & 0.000352 & centimeter per second $(\mathrm{cm} / \mathrm{s})$ \\
\hline \multicolumn{3}{|c|}{ Transmissivity* } \\
\hline foot squared per day $\left(\mathrm{ft}^{2} / \mathrm{d}\right)$ & 0.09290 & meter squared per day $\left(\mathrm{m}^{2} / \mathrm{d}\right)$ \\
\hline
\end{tabular}

Temperature in degrees Fahrenheit $\left({ }^{\circ} \mathrm{F}\right)$ may be converted to degrees Celsius $\left({ }^{\circ} \mathrm{C}\right)$ as follows:

$$
{ }^{\circ} \mathrm{C}=\left({ }^{\circ} \mathrm{F}-32\right) / 1.8
$$

\section{Datums}

Vertical coordinate information is referenced to the North American Vertical Datum of 1988 (NAVD 88).

*Transmissivity: The standard unit for transmissivity is cubic foot per day per square foot times foot of aquifer thickness [(ft $\left.\left.\mathrm{ft}^{3} / \mathrm{d}\right) / \mathrm{ft}^{2}\right] \mathrm{ft}$. In this report, the mathematically reduced form, foot squared per day $\left(\mathrm{ft}^{2} / \mathrm{d}\right)$, is used for convenience.

Borehole electromagnetic conductivity is given in millisiemens per meter $(\mu \mathrm{S} / \mathrm{m})$. A millisiemen per meter is equal to 10 microsiemens per centimeter $(\mu \mathrm{S} / \mathrm{cm})$. One millisiemen is equivalent to one millimho.

Electrical resistance of water in the wellbore is reported in units of ohm-meters (Ohm-M).

Natural gamma log results are reported in gamma counts per second (CPS).

Several types of orientation relative to horizontal and vertical direction are reported in degrees relative to a reference.

Azimuth is reported in degrees relative to north or zero (0) degrees and ranges from zero to 360 degrees.

Tilt of a borehole is reported in degrees relative to vertical, where zero (0) degrees is vertical and tilt varies from 0 to 90 degrees. 


\section{Abbreviations}

\begin{tabular}{|c|c|}
\hline ATV & acoustic televiewer (geophysical logging tool) \\
\hline Azi & azimuth \\
\hline CPS & counts per second of natural gamma radiation emissions \\
\hline EM & electromagnetic \\
\hline FLASH & Flow Log Analysis of Single Holes \\
\hline Flow amb & $\begin{array}{l}\text { vertical flow measured by electromagnetic flowmeter during ambient, } \\
\text { non-stressed conditions }\end{array}$ \\
\hline Flow pmp & $\begin{array}{l}\text { vertical flow measured by electromagnetic flowmeter during pumping-stressed } \\
\text { conditions }\end{array}$ \\
\hline Fl res amb & $\begin{array}{l}\text { fluid resistivity measured with fluid resistivity geophysical tool during ambient, } \\
\text { non-stressed conditions }\end{array}$ \\
\hline Fl res pmp & $\begin{array}{l}\text { fluid resistivity measured with fluid resistivity geophysical tool during pumping- } \\
\text { stressed conditions }\end{array}$ \\
\hline GPS & global positioning system \\
\hline HIC & Hannahville Indian Community \\
\hline МMHO/M & $\begin{array}{l}\text { Conductivity measured in millimhos per meter. Equivalent to one MilliSiemen } \\
\text { per meter. }\end{array}$ \\
\hline NED & National Elevation Dataset \\
\hline OTV & optical televiewer (geophysical logging tool) \\
\hline Temp amb & fluid temperature measured during ambient, non-stressed conditions \\
\hline Temp pmp & fluid temperature measured during pumping-stressed conditions \\
\hline USGS & U.S. Geological Survey \\
\hline
\end{tabular}





\title{
Geophysical-Log and Hydraulic-Test Analyses of Groundwater-Production Wells at the Hannahville Indian Community, Menominee County, Michigan
}

\author{
By E. Randall Bayless, J. Alton Anderson, David C. Lampe, and John H. Williams
}

\section{Abstract}

The U.S. Geological Survey, in cooperation with the Hannahville Indian Community, evaluated the geohydrology of the bedrock formations and hydraulic properties of groundwater-production wells at the Hannahville Indian Community in Menominee County, Michigan. Geophysical logs were collected from five wells at two sites during September 2012. The logs were analyzed to characterize the lithostratigraphy, bedding and fractures, and hydraulic properties of the geologic formations and aquifers beneath the Hannahville Indian Community. The geophysical logs collected included natural gamma radiation, electromagnetic conductivity, wellbore image, caliper, ambient and stressed flowmeter, fluid resistivity, temperature, and wellbore deviation. The geophysical logs were analyzed with results from short-term hydraulic tests to estimate the transmissivity and water-level altitudes of flow zones penetrated by the wells.

The geophysical log analysis indicated the wells penetrated four distinct lithostratigraphic units - shale and carbonate rock, upper carbonate rock, carbonate rock and glauconitic sandstone, and lower carbonate rock. Most of the fractures penetrated by the wellbores appeared to be related bedding partings. The lower carbonate rock unit contained solution features.

Analysis of the geophysical logs and hydraulic tests indicated that each of the five wells penetrated from one to four flow zones. The Casino 5 well penetrated a flow zone that was associated with solution features and had an estimated total transmissivity of 4,280 feet squared per day $\left(\mathrm{ft}^{2} / \mathrm{d}\right)$, the highest estimate for all the wells. The Casino 3 well penetrated four flow zones and had an estimated total transmissivity of $3,570 \mathrm{ft}^{2} / \mathrm{d}$. The flow zones penetrated in the lower carbonate rock unit by the Casino 3 and 5 wells were hydraulically connected. The Golf Shack well penetrated two flow zones and had an estimated total transmissivity of $40 \mathrm{ft}^{2} / \mathrm{d}$, the lowest estimate for all the wells. The Community 1 and Community 2 wells penetrated three and four flow zones, respectively, and had estimated total transmissivity values of 185 and $280 \mathrm{ft}^{2} / \mathrm{d}$, respectively.

\section{Introduction}

The Hannahville Indian Community (HIC), in Michigan's Upper Peninsula, is experiencing considerable population growth, as well as increased demand for water from tribaloperated facilities (fig. 1). As the demand increases for water resources, the capacity of the tribal water-supply system also must grow to meet the needs of the HIC. Water-resource managers require information to describe the current resource and locate potential sources of future water supplies. Although groundwater supplies generally appear to be abundant, they may be locally insufficient as a result of aquifer characteristics or poor groundwater quality. In this study, geophysical logging and hydraulic-testing methods were used to gather data to characterize the lithostratigraphy, fractures, and hydraulic properties of the Cambrian-Ordovician aquifer system penetrated by the groundwater-production wells (fig. 2). This report describes the methods used to interpret data from borehole geophysical logs collected in five wells and the subsequent analyses of those geophysical logs for characterizing the hydrogeologic properties of bedrock underlying the HIC.

One aspect of the mission of the U.S. Geological Survey (USGS) is to provide reliable scientific information that describes the availability of water resources in the Nation, including the geologic framework of aquifers. This investigation provides a needed case study of how borehole geophysical methods can assist in characterizing the water stored and transmitted in a part of the Cambrian-Ordovician aquifer system, an aerially extensive aquifer across the Midwest United States. Availability of groundwater resources from this aquifer varies because of an irregular distribution of fractures, dissolution-modified voids, and stratigraphic-based permeability within the aquifer. Following the guidelines within our strategic science direction, the USGS works with its cooperative partners, including Tribal partners, to document how emerging scientific methods can be effectively applied to better understand the distribution of groundwater resources. 


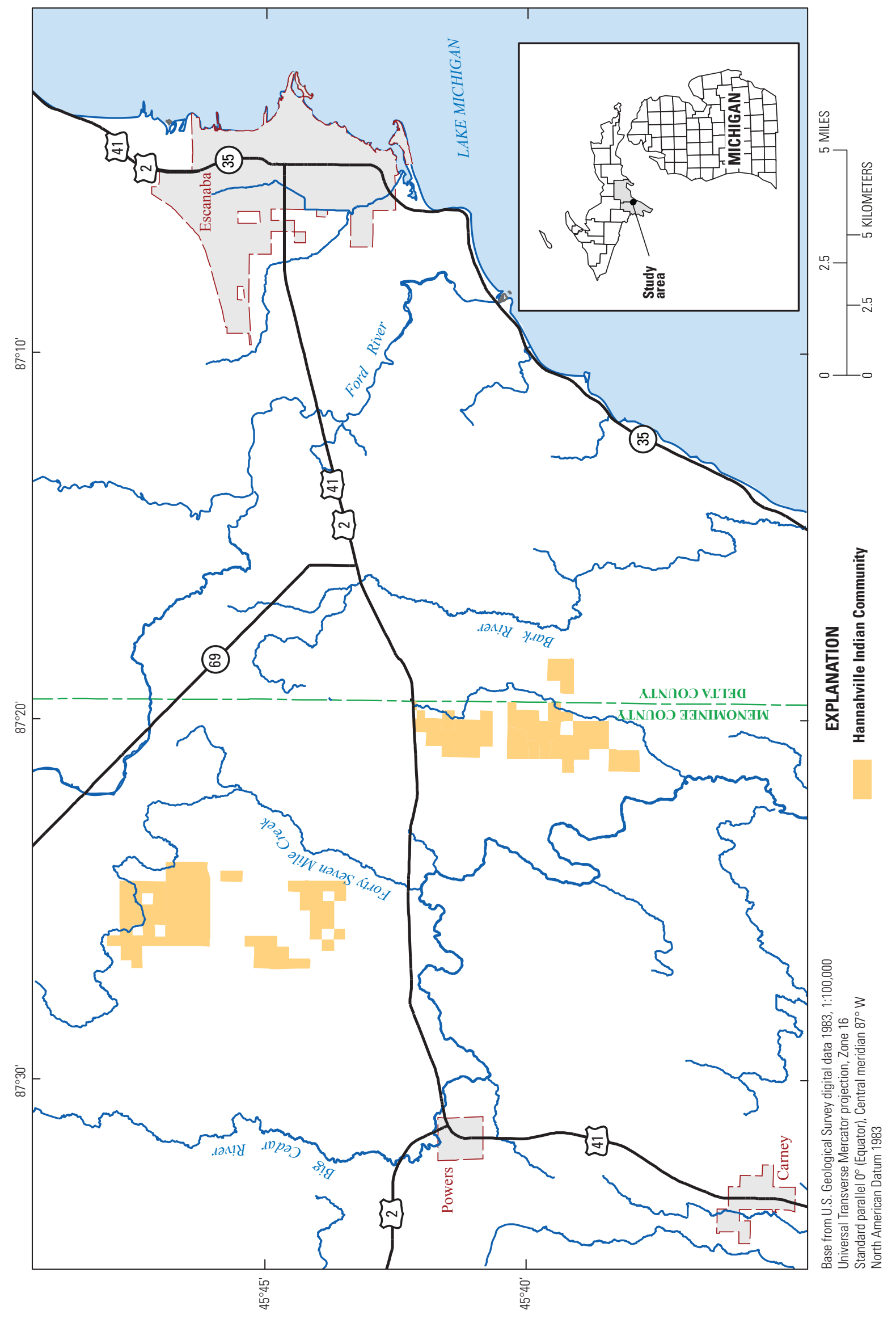

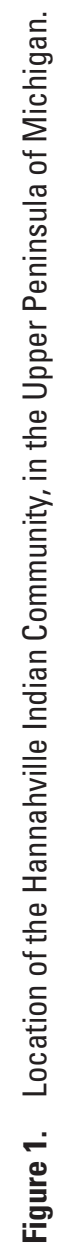




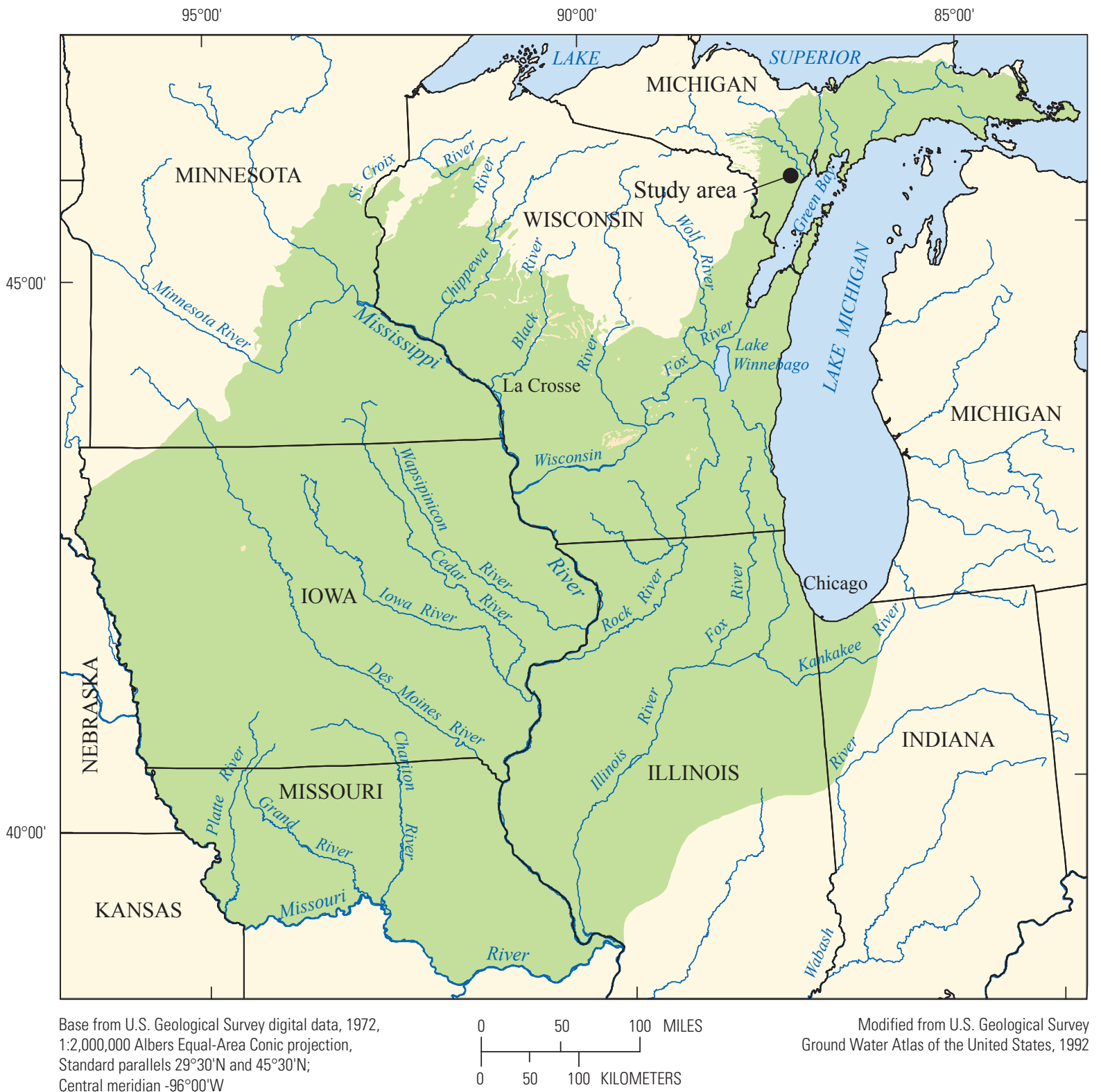

Central meridian $-96^{\circ} 00^{\prime} \mathrm{W}$

\section{EXPLANATION}

Cambrian-Ordovician aquifer system

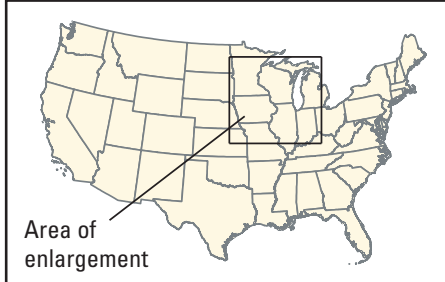

Figure 2. Location of the Cambrian-Ordovician aquifer system, and the study area in the northern Midwest of the United States. 
Geophysical-Log and Hydraulic-Test Analyses of Groundwater Wells, Hannahville Indian Community, Michigan

\section{Purpose and Scope}

This report documents the application of borehole geophysical techniques at five groundwater-production wells in the HIC to understand hydrogeologic factors that affect differences in yield of water from the wells. The report describes the methods used to collect the data, techniques used to analyze the information, and the resulting description of the hydrogeology. The report demonstrates the application of borehole geophysical techniques and methods to characterize permeable features of sedimentary bedrock aquifers and how that information can be used for water-resource managers in planning, protecting, and developing local groundwater supplies. Techniques include single and cross-hole aquifer tests, and borehole geophysical measurements with caliper, electromagnetic induction, natural gamma, optical televiewer, acoustic televiewer, and electromagnetic flowmeter tools. The report benefits the USGS by demonstrating the application of these techniques and methods to characterize the CambrianOrdovician aquifer system.

\section{Previous Investigations}

There are few published reports describing the groundwater resources of Menominee County, Michigan. Vanlier (1963) described the hydrogeology and general groundwater quality of Menominee County. Sloan (1997) presented a wellhead-protection program for the HIC, including general hydrogeologic information, potential sources of groundwater contamination, and proposed wellhead-protection areas for the groundwater-production wells. Regional studies of the Cambrian-Ordovician formations indicate that groundwater use in the Upper Peninsula of Michigan is generally limited to domestic supplies (Olcott, 1992).

\section{Description of the Study Area}

The HIC is located approximately 13 miles (mi) west of Escanaba, Michigan (fig. 1). The HIC includes about 5,600 acres of land, mostly located in Menominee County. The population of Menominee County is about 23,930 (U.S. Census Bureau, 2012).

The HIC is in the Big Cedar River Watershed, and the Big Cedar River drains to Lake Michigan. The average annual precipitation in the study area is about 28.7 inches per year (in/yr), distributed over 118 days (http://www.ncdc.noaa. gov/land-based-station-data/climate-normals; last accessed February 13, 2013).

\section{Hydrogeologic Setting}

The HIC is underlain by glacial drift and Cambrian- and Ordovician-age bedrocks of mixed lithologies (table 1). These bedrock units are part of the Cambrian-Ordovician aquifer system, which underlies about 179,000 square miles $\left(\mathrm{mi}^{2}\right)$ in parts of seven States in the northern Midwest (Illinois, Indiana,
Iowa, Michigan (Upper Peninsula), Minnesota, Missouri, and Wisconsin) (fig. 2). The Cambrian-Ordovician aquifer system is designated as 1 of 16 sandstone principal aquifers that underlie the United States (U.S. Geological Survey, 2003), but also includes several carbonate (limestone and dolomite) rock units with shale layers.

Most of Menominee County is overlain by some thickness of glacial deposits (Vanlier, 1963); including an extensive drumlin field that forms northeast-southwest trending ridges across the study area (Sloan, 1997). The area near the HIC is overlain with fine-grained deposits that generally are not adequate to supply water in excess of rural domestic demands. These deposits include mixtures of clay, silt, sand, and gravel (Sloan, 1997). Coarse-grained glacial deposits with relatively productive aquifers are generally limited to the southeastern part of Menominee County. The thickness of glacial deposits at three groundwater-production wells in the HIC ranged from 0 to 9 feet (ft) (Sloan, 1997). For groundwater-modeling purposes, Sloan (1997) estimated the porosity of the glacial deposits (drift) to be 0.40 and the hydraulic conductivity to range from $2.83 \times 10^{-7}$ to $2.83 \times 10^{-1}$ feet per day $(\mathrm{ft} / \mathrm{d})$.

The Upper Limestone rock unit includes the Trenton Limestone and Black River Limestone and is the uppermost bedrock aquifer beneath the HIC (table 1). Combined thickness of these units ranges from 0 to $300 \mathrm{ft}$ in Menominee County. The bedrock in Menominee County dips to the southeast from the eastern flank of the Wisconsin Dome into the Michigan Basin and slopes from northwest to southeast (fig. 9 in Olcott, 1992). Regional groundwater-flow directions follow the bedrock dip to the southeast toward Green Bay and Lake Michigan (Sloan, 1997). Vanlier (1963) described the limestone and dolomite beds within these units as the primary source of water in the area, but Sloan (1997) indicated that these units also may act as a cap rock for deeper aquifers. Wells in the Upper Limestone commonly range from 30 to $300 \mathrm{ft}$ in depth and commonly provide 5-10 gallons per minute (gal/min), yields described by Vanlier (1963) as sufficient for domestic and farm use. In some localities, wells may produce up to $100 \mathrm{gal} / \mathrm{min}$. Water in these rock units may be hard and contain iron that exceeds aesthetic standards but it is otherwise typically satisfactory for most uses.

Groundwater flows in the Upper Limestone rock unit through preferential-flow features that include bedding partings, joints, and other fractures (Sloan, 1997). Gravels formed from weathered bedrock and those that rest on the bedrock surface of the Upper Limestone rock unit may be the most productive unconsolidated deposit (Vanlier, 1963). Recharge to the Upper Limestone rock unit may occur as downward migration of infiltrating precipitation through the overlying glacial deposits or as horizontal flow to the southeast along the regional dip from upgradient bedrock sources. Recharge to the Upper Limestone rock unit through the glacial drift may be retarded by the low permeability of fine-grained deposits. Hydraulic conductivity of the bedrock aquifers was estimated by Sloan (1997) to be 0.28 to $0.00028 \mathrm{ft} / \mathrm{d}$, for groundwatermodeling purposes. 
Table 1. Generalized stratigraphy in the vicinity of the Hannahville Indian Community, Menominee County, Michigan.

[Modified from Sloan, 1997; ft, foot; gal/min, gallon per minute]

\begin{tabular}{|c|c|c|c|c|c|}
\hline Geologic names & Geologic age & Aquifer & $\begin{array}{l}\text { Thickness, } \\
\text { in feet }\end{array}$ & Lithology & Characteristics \\
\hline Glacial Drift & Quaternary & Glacial Drift & $0-200$ & $\begin{array}{l}\text { Mixture of clay, silt, } \\
\text { sand, and gravel }\end{array}$ & $\begin{array}{l}\text { Water yielded from coarse } \\
\text { gravel beds }\end{array}$ \\
\hline $\begin{array}{l}\text { Trenton Limestone and } \\
\text { Black River Limestone }\end{array}$ & Middle Ordovician & $\begin{array}{l}\text { Upper Lime- } \\
\text { stones }\end{array}$ & $0-300$ & $\begin{array}{l}\text { Beds of limestone, } \\
\text { dolomite, and shale }\end{array}$ & $\begin{array}{l}\text { Wells depths are generally } \\
\text { less than } 40 \mathrm{ft}\end{array}$ \\
\hline $\begin{array}{c}\text { Franconia Sandstone and } \\
\text { Dresbach Sandstone }\end{array}$ & Cambrian & $\begin{array}{l}\text { Lower sand- } \\
\text { stones }\end{array}$ & $50-200$ & $\begin{array}{l}\text { Beds of pink, gray, and } \\
\text { white sandstone }\end{array}$ & $\begin{array}{l}\text { When confined by the upper } \\
\text { limestone and the middle } \\
\text { limestone and sand- } \\
\text { stone aquifers, will yield } \\
200-300 \mathrm{gal} / \mathrm{min}\end{array}$ \\
\hline $\begin{array}{l}\text { Michigamme Slate/ } \\
\text { Randville Dolomite }\end{array}$ & Precambrian & $\begin{array}{l}\text { Precambrian } \\
\text { rocks }\end{array}$ & $\begin{array}{l}1000 \text { 's of feet } \\
\text { in thickness }\end{array}$ & $\begin{array}{c}\text { Dark gray-green schist, } \\
\text { called "green" stone }\end{array}$ & $\begin{array}{l}\text { Permeability results princi- } \\
\text { pally from fractures }\end{array}$ \\
\hline
\end{tabular}

Rock units of the early Ordovician age Prairie du Chien Group, contain sandstone and dolomite rock units. The lithology of the Prairie du Chien Group includes sandstones, limestones and dolostones. The Prairie du Chien Group overlies the Cambrian bedrock. The Prairie du Chien Group is the deepest geologic unit commonly used for water supply in Menominee County. Wells completed in the Prairie du Chien Group are 30-200 ft deep and are commonly utilized where water from the shallower Trenton and Black River Limestones contain excessive dissolved sulfate (Vanlier, 1963).

The Franconia and Dresbach Sandstones of Cambrian age consist of pink, gray, and white sandstone. These sandstones may yield 200-300 gal/min but are not typically utilized for water supplies in eastern Menominee County. The Franconia and Dresbach Sandstones underlie the Prairie du Chien Group of Ordovician age (table 1) and are more often referred to as the Munising Formation.

\section{Description of the Groundwater-Production Wells}

The five wells evaluated in this study were all cased through the glacial drift and completed as open holes in the bedrock. Well-location information was acquired from a handheld global-positioning system (GPS) unit, and land-surface altitude information was generated by the USGS National Elevation Dataset (NED) web service (http://gisdata.usgs. net/XMLWebServices2/Elevation; last accessed 02/14/2013). Construction information for the five wells is presented in table 2.

Three wells (Casino 3, Casino 5, and Golf Shack) are on Island Resort \& Casino property. These wells provide water to the Island Resort \& Casino, a convention center, a gas station, a convenience store, a water-treatment plant, a wastewatertreatment plant, and a recreational vehicle park for drinking, sanitary, recreational, commercial, and other operational needs. The average use is about 30,000 gallons per day ( $\mathrm{gal} / \mathrm{d}$ ) (Sloan, 1997). The wells penetrated about $9 \mathrm{ft}$ of glacial drift and up to $350 \mathrm{ft}$ of bedrock. Sloan (1997) indicated that the capacity of these wells was about 100,300 , and $530 \mathrm{gal} / \mathrm{min}$, respectively, and the HIC reported that the withdrawal was about 100-180 gal/min per well.

Two wells (Community 1 and Community 2 ) provide water for drinking, sanitary, and other needs to homes, a school, and general HIC operations (Sloan, 1997). These wells penetrate about $50 \mathrm{ft}$ of glacial drift and up to $300 \mathrm{ft}$ of bedrock approximately $3 \mathrm{mi}$ south of the other wells used in this study. Sloan (1997) indicated the capacity of the wells was about $150 \mathrm{gal} / \mathrm{min}$; however, the HIC reports that water withdrawals are about $75 \mathrm{gal} / \mathrm{min}$. 
Table 2. Land-surface elevation and construction for five groundwater-production wells, Hannahville Indian Community, Menominee County, Michigan.

[USGS, U.S. Geological Survey; NAVD 88, North American Vertical Datum of 1988]

\begin{tabular}{llcccc}
\hline $\begin{array}{c}\text { USGS } \\
\text { station name }\end{array}$ & Local name & $\begin{array}{c}\text { Land-surface elevation, } \\
\text { in feet above NAVD 881 }\end{array}$ & $\begin{array}{c}\text { Well depth, } \\
\text { in feet below land surface }\end{array}$ & $\begin{array}{c}\text { Well diameter, } \\
\text { in inches }\end{array}$ & $\begin{array}{c}\text { Casing depth, } \\
\text { in feet below land surface }\end{array}$ \\
\hline $38-25 \mathrm{C} 3$ & Casino 3 & 759 & 351 & 8 & 128 \\
$38-25 \mathrm{C5}$ & Casino 5 & 761 & 354 & 10 & 309 \\
$38-25 \mathrm{GS}$ & Golf shack & 775 & 223 & 6 & 25 \\
$38-25 \mathrm{CO} 1$ & Community 1 & 728 & 303 & 6 & 64 \\
$38-25 \mathrm{CO} 3$ & Community 2 & 727 & 352 & 8 & 71 \\
\hline
\end{tabular}

${ }^{1}$ Estimated to nearest foot using the USGS National Elevation Dataset (NED) Web service (http://gisdata.usgs.net/XMLWebServices2/Elevation).

\section{Methods of Study}

Geophysical logging and hydraulic-testing methods were used to characterize the geohydrologic properties of parts of the bedrock aquifer penetrated by and open to the wells. These geophysical and hydraulic methods are described in the following sections.

\section{Geophysical Logs}

Geophysical characteristics of the rock units were used to describe the lithostratigraphy, fractures, and groundwaterflow zones penetrated by the wells. Flow zones are intervals of the borehole where groundwater is flowing at measureable rates and contributing to the computed well yield. Several borehole geophysical probes were run in the five wells to collect geophysical logs; these logs included natural-gamma, electromagnetic (EM) induction, wellbore-image, caliper, flow, fluid resistivity and temperature, and wellbore deviation (appendix 1). The geologic and hydrologic characteristics measured by the geophysical probes are briefly described in this section. Additional information on these types of geophysical logs is presented in Keys (1990) and Rider and Kennedy (2011).

Natural-gamma (Gamma) logs record the measured gamma radiation naturally emitted by geologic formations in units of counts per second (CPS) of the rock units penetrated by the wellbore. Clays tend to accumulate radioisotopes through adsorption and ion-exchange processes, and intervals of high gamma counts are typically interpreted as being clay rich. Shale, glauconitic sandstones, and organic-rich sediments also are associated with high gamma responses (Keys, 1990). The natural gamma tool used for this study has a vertical resolution of 1 to $2 \mathrm{ft}$. Gamma logs collected in open boreholes and through steel casing as part of this study were used for lithologic identification. Natural gamma measurements in large diameter wells or through steel well casing may be partially attenuated (Collier, 1993).
Electromagnetic-induction (Cond) logs record the electrical conductivity of geologic materials (glacial deposits and bedrock) and water surrounding the wellbore in units of millisiemens per meter $(\mu \mathrm{S} / \mathrm{m})$. Electrical conductivity measurements are affected by the clay content and porosity of the rocks and by the conductivity of the pore fluid. The EM induction tool has a vertical resolution of $2 \mathrm{ft}$ and generally is not affected by the electrical conductivity of the fluid in wellbores that are less than 8 inches (in.) in diameter. EM-induction logs collected as part of this study were used to identify the base of the casing and for lithologic identification in the open wellbore.

Optical televiewer (OTV) logs record a 360-degree, magnetically oriented, optical image of the wellbore wall or open borehole. OTV logs can be collected above the water level and in clear water. The OTV logs were used to identify and inspect the base of the casing and to characterize well construction and lithologic, structural, and solution features penetrated in the open borehole. The OTV logs were used to determine the strike and dip of planar structural features (bedding and fractures). Vertical striping that appears on the logs is caused by decentralization of the acoustic televiewer and does not represent lithologic or borehole changes.

Acoustic-televiewer (ATV) logs record a 360-degree magnetically oriented acoustic image of the wellbore wall. ATV logs can be collected in clear or turbid water. The ATV logs were used to characterize well construction and lithologic, structural, and solution features penetrated by the wells. The ATV logs also were used to determine the strike and dip of identified planar structural features (bedding and fractures).

Caliper logs record measurements of the diameter of the borehole in inches. Changes in wellbore diameter relate to drilling and construction procedures and competency of lithologic units, fractures, and solution features in bedrock aquifers. Caliper logs were collected with a spring-loaded, three-arm averaging probe. Caliper logs were used to delineate fractures, solution features, and wellbore wall rugosity and to confirm well and casing depths and diameters. 
Flow (Flow amb/Flow pmp) logs record the direction and rate of vertical flow in the wellbore in gallons per minute. Flow was measured using an EM-flowmeter as described by Young and Pearson (1995). The EM-flowmeter used in this study had a fully fitted diverter (flush with borehole diameter); the EM-flowmeter has a flow measurement range of 0.05 to $15 \mathrm{gal} / \mathrm{min}$. Ambient flow occurs in the wellbore if the well is open to two or more flow zones in the aquifer that have comparably different hydraulic heads. Under those conditions, ambient inflow to the wellbore is from a flow zone or zones that have higher hydraulic heads (compared to the overall composite water level in the open borehole) to an outflow zone or zones that have lower heads. The composite water level is the ambient water level in the well that represents the combined hydraulic head of all zones intercepted by the well. The ambient fluid resistivity and temperature logs were used to identify possible flow zones, and the ATV, OTV, and caliper logs were used to locate competent wellbore intervals for flow $\log$ measurement stations between those flow zones. Stationary flow measurements were made under ambient (Flow amb) and pumped (Flow pmp) conditions as described in the section of this report titled "Hydraulic Tests."

Fluid resistivity (Fl res amb/Fl res pmp) logs record the electrical resistivity of water in the wellbore in ohm-meters (Ohm-M). The electrical resistivity measured by the log is related to the concentration of dissolved solids in the water. Curve deviations in fluid-resistivity logs may indicate zones of inflow to a wellbore from the aquifer or outflow from a wellbore to the aquifer. Fluid-resistivity logs were used to identify possible flow zones in the wellbore and to delineate possible changes in wellbore flow. Ambient fluid resistivity (Fl res amb) logs were collected immediately before the ambient flow measurements were made. Pumping fluid resistivity (Fl res pmp) logs were collected immediately before and after the pumping flow measurements were made. Wellbore flow under quasi-steady stress reached equilibrium quickly; however, fluid properties can change over time and the sequential pumping fluid-resistivity logs can provide additional information.

Temperature (Temp amb/Temp pmp) logs measure the water temperature in the wellbore in degrees Fahrenheit. Temperature gradients that are smaller than the geothermal gradient may indicate intervals of groundwater flow into or out from the wellbore; the geothermal gradient is the rate of temperature increase relative to increasing depth into the Earth. Temperature logs were used to delineate the groundwater level in a well and possible changes in wellbore flow. Ambient fluid temperature (Fl temp amb) logs were collected immediately before the ambient flow measurements were made. Pumping fluid temperature ( $\mathrm{Fl}$ temp pmp) logs were collected immediately before and after the pumping flow measurements were made.

Azimuth and tilt (Azi/Tilt) logs record the deviation (tilt and azimuth) of the wellbore from vertical, in degrees. A truly vertical wellbore has a deviation of 0 degrees. Borehole-deviation logs were collected with three-axis fluxgate magnetometers and vertical inclinometers that are incorporated in the OTV and ATV tools. The wellbore inclination or tilt generally is measured within \pm 0.5 degree throughout the wellbore and the azimuth direction within \pm 2 degrees below the steel casing. The deviation logs collected using the OTV and ATV tools were within the measurement error. The deviation of the wellbores from vertical was less than 4 degrees. The deviation log from the OTV tool is presented in appendix 1 and was used to correct the apparent strike and dip of planar features identified on the image logs to their true strike and dip.

\section{Hydraulic Tests}

Hydraulic testing was used in conjunction with flow logging to characterize the transmissivity, hydraulic head, and hydraulic connection of flow zones in the rock units intercepted by the wells. Ambient flow, fluid resistivity, and temperature logs from the wells were collected under ambient conditions (stabilized non-pumping water-level conditions) prior to the hydraulic tests. Following collection of the ambient logs, the hydraulic tests were conducted by pumping the well at a constant rate using the submersible pump set near the top of the water column, and in the well casing above the interval of the well open to the rock units. The pump was set below the well casing in the Golf Shack well because the water level was below the well casing. Drawdown in the well was measured at 10 second intervals using a pressure transducer with an internal data logger. Check measurements were made periodically with an electric water-level tape. Quasisteady-state drawdown conditions (water level change of less than $0.1 \mathrm{ft}$ in 10 minutes) under constant-rate pumping were achieved before and maintained during the collection of the pumped flow, fluid resistivity, and temperature logs.

The total transmissivity of the open interval for each well was estimated from its calculated specific capacity (pumping rate divided by the quasi-steady-state drawdown) through the application of a computer program developed by Bradbury and Rothschild (1985). The program uses an iterative procedure to replace the graphical method of estimating transmissivity from specific capacity described by Theis and others (1964). A common confined-aquifer storage coefficient of $5 \times 10^{-5}$ was assumed in the analysis.

The transmissivity and hydraulic head of each detected flow zone penetrated by the wells was estimated from the total transmissivity, quasi-steady-state drawdown, and ambient- and stressed-condition flow logs through the application of the computer program FLASH (Flow Log Analysis of Single Holes) developed by Day-Lewis and others (2011). The FLASH program uses a multi-layer, analytical solution for steady-state radial flow to a single borehole based on the Thiem equation (Thiem, 1906).

The hydraulic connection between the flow zones penetrated by the Casino 3 and 5 wells was characterized by cross-well flow testing as described by Paillet (1998) and 
Williams and Paillet (2002). Time-dependent changes in flow (transient flow) were measured between the upper and lower flow zones in the Casino 3 well while withdrawing water from the Casino 5 well. The Casino 3 well is about $775 \mathrm{ft}$ north of the Casino 5 well. The measured transient flow response was matched with that simulated by the Paillet (1998) model by adjusting flow-zone transmissivity, storage coefficient, and connection geometry.

\section{Geophysical-Log and Hydraulic-Test Analyses}

The results from geophysical logs and hydraulic tests were used to characterize the lithostratigraphy, bedding, fractures, and flow zones of rock units penetrated by the five wells evaluated in this investigation. Composites of the geophysical logs and their analyses are presented in figures 1-1 through 1-5. A section showing lithostratigraphy, natural gamma, and flow zones is presented in figure 3 .

\section{Lithostratigraphy}

The geophysical-log analysis indicated the five wells penetrated four distinct lithostratigraphic (based on the physical and mineral properties of the rock) or rock units (figs. 1-1 through 1-5). The lithostratigraphic units in descending order were (1) shale and carbonate rock unit, (2) upper carbonate rock unit, (3) carbonate rock and glauconitic sandstone unit, and (4) lower carbonate rock unit.

Geophysical logs revealed some variability in characteristics of the shale and carbonate rock unit. The shale and carbonate rock unit was penetrated from 9 to $87 \mathrm{ft}$ below land surface in the Casino 3 well, from 13 to $81 \mathrm{ft}$ below land surface in the Casino 5 well, from 15 to $85.5 \mathrm{ft}$ below land surface in the Golf Shack well, from 48 to $105 \mathrm{ft}$ below land surface in the Community 1 well, and from 49 to $105 \mathrm{ft}$ below land surface in the Community 2 well. The shale and carbonate rock unit displayed relatively high natural gamma counts and EM-conductivity values; EM-conductivity logs could not be collected for these lithostratigraphic units because the steel well casing extended through the entire interval. The gamma and conductivity logs were closely correlated indicating that these logs reflected shale content. The gamma values ranged from 50 to 300 CPS. The electrical conductivity of the shale and carbonate rock unit ranged from less than 10 to about $40 \mu \mathrm{S} / \mathrm{m}$, which was the highest measured value in any of the lithostratigraphic units. The shale and carbonate rock unit had alternating dark gray to brown beds in OTV logs and ranged in thickness from less than 1 in. to several feet. The color change between beds was less obvious in the Golf Shack, Community 1 , and Community 2 wells owing to turbidity in the wellbore water column. The dip of the bedding ranged from nearly horizontal to 15 degrees with the primary dip direction to the east.

The geophysical logs indicated less variability in hydrogeologic characteristics than were observed in the shale and carbonate rock unit. The upper carbonate rock unit was penetrated from 87 to $182 \mathrm{ft}$ below land surface in the Casino 3 well, from 81 to $180 \mathrm{ft}$ below land surface in the Casino 5 well, from 89 to $187 \mathrm{ft}$ below land surface in the Golf Shack well, from 105 to $160 \mathrm{ft}$ below land surface in the Community 1 well, and from 105 to $163 \mathrm{ft}$ in the Community 2 well. The upper carbonate rock unit had low overall gamma and electrical conductivity values with relatively little variation, which reflects the low shale and glauconite content. The gamma values measured in the upper carbonate rock unit ranged from 25 to $120 \mathrm{CPS}$. The electrical conductivity values in the upper carbonate rock unit ranged from 5 to $10 \mu \mathrm{S} / \mathrm{m}$, except for those in the Casino 3 well, which had conductivity values from 20 to $25 \mu \mathrm{S} / \mathrm{m}$. The upper carbonate rock unit had alternating light white/buff to dark gray beds. Color change was less obvious in the Golf Shack, Community 1, and Community 2 wells owing to turbidity in the water column. The beds ranged in thickness from less than 1 in. to tens of feet. The dip of the beds ranged from nearly horizontal to 15 degrees with the primary dip direction to the east. These observations were generally consistent with the dip of the overlying shale and carbonate rock units.

The presence of glauconite had a noticeable impact on geophysical measurements within the carbonate rock and glauconitic sandstone unit. The carbonate rock and glauconitic sandstone unit had large gamma variation with values ranging from as low as 20 to above $250 \mathrm{CPS}$. Elevated gamma values are believed to reflect elevated glauconititc content (generally greenish illitic clay) in the sandstone. The carbonate rock and glauconitic sandstone unit was penetrated from 182 to $314 \mathrm{ft}$ below land surface in the Casino 3 well, from 180 to $335 \mathrm{ft}$ below land surface in the Casino 5 well, from $187 \mathrm{ft}$ to at least the bottom of the well at $223 \mathrm{ft}$ below land surface in the Golf Shack well, from $160 \mathrm{ft}$ to at least the bottom of the well at $303 \mathrm{ft}$ below land surface in the Community 1 well, and from 163 to $310 \mathrm{ft}$ below land surface in the Community 2 well. The steel casing prevented EM logging of most of this interval in the Casino 5 well. Both the Golf Shack and Community 1 wells terminated in the glauconitic sandstone unit. The electrical conductivity of the formation had some variation, with measurements from 5 to $20 \mu \mathrm{S} / \mathrm{m}$. The carbonate rock and glauconitic sandstone unit had light gray/tan bedding with zones of light gray/green glauconitic sandstone in OTV images, which correspond to high gamma measurements (above 100 CPS). Darker, multiple feet thicknesses of tan colored beds are present in the top 20-30 ft of the unit. These beds have higher gamma counts but little change in formation conductivity. The color change was less obvious in the Community 1 and 2 wells owing to turbidity in the wellbore water. The dip of the beds ranged from 10 to 30 degrees with the primary dip direction to the east-northeast. 
The lower carbonate rock unit had the lowest overall gamma counts, with values below $50 \mathrm{CPS}$, indicating low shale and glauconite content. The top of the lower carbonate rock unit was penetrated by the Casino 3, Casino 5, and Community 2 wells at 314, 335, and $310 \mathrm{ft}$ below land surface, respectively. These wells terminated in the lower carbonate rock unit. The formation conductivity displayed little variation, with values primarily from 10 to $15 \mu \mathrm{S} / \mathrm{m}$, except for the Casino 3 well, which had values from 15 to $20 \mu \mathrm{S} / \mathrm{m}$. The lower carbonate rock unit was distinguished by light gray to buff vuggy beds with pipe-like solution features, which alternated with thinner, and more competent, light graygreen and tan beds. The vuggy beds ranged in thickness from less than $1 \mathrm{ft}$ to multiple feet. The solution features ranged from less than one to multiple inches in diameter (fig. 4). The measured dip of the beds ranged from 15 to 20 degrees with the primary dip direction to the north-northeast.

\section{Fractures}

Most of the fractures penetrated by the wells appeared to be along bedding partings. The fractures generally dipped less than 20 degrees with no preferred dip direction. A few south-dipping high-angle fractures (fractures with dips greater than 60 degrees) were identified in the carbonate rock and glauconitic sandstone unit. The carbonate rock and glauconitic sandstone unit also had the highest fracture density among the units measured in this investigation. The majority of the fractures were in the upper $50 \mathrm{ft}$ of the carbonate rock and glauconitic sandstone unit.

\section{Flow Zones}

One to four flow zones associated with bedding partings and (or) solution features that displayed a wide range of transmissivity values were penetrated by the wells. The distribution, lithostratigraphic unit and structural characteristics, and hydraulic properties of the flow zones penetrated by each well are presented below, and a summary of test results is provided in table 3.

The Casino 3 well had an estimated total transmissivity of 3,570 feet squared per day $\left(\mathrm{ft}^{2} / \mathrm{d}\right)$ and composite water-level altitude of $708.0 \mathrm{ft}$ above the North American Vertical Datum of 1988 (NAVD 88) (table 3). Flow zones were penetrated by the well at 144, 198, 247, and 332 to $350 \mathrm{ft}$ below land surface. The $144 \mathrm{ft}$ zone was in the upper carbonate unit and was associated with bedding partings. The zone had an estimated transmissivity of $675 \mathrm{ft}^{2} / \mathrm{d}$ and an estimated waterlevel altitude of $707.9 \mathrm{ft}$. The 198 and $247 \mathrm{ft}$ zones were in the carbonate rock and glauconitic sandstone unit and were associated with bedding partings. The $198 \mathrm{ft}$ zone had an estimated transmissivity of $25 \mathrm{ft}^{2} / \mathrm{d}$ and an estimated water-level altitude of $711.0 \mathrm{ft}$. The $247 \mathrm{ft}$ zone had an estimated transmissivity of $1,830 \mathrm{ft}^{2} / \mathrm{d}$ and an estimated water-level altitude of $708.0 \mathrm{ft}$.
The 332 to $350 \mathrm{ft}$ zone was associated with the vuggy beds of the lower carbonate rock unit. The flow zone had an estimated transmissivity of $1,040 \mathrm{ft}^{2} / \mathrm{d}$ and an estimated water-level altitude of $707.9 \mathrm{ft}$.

The Casino 5 well had an estimated total transmissivity of $4,280 \mathrm{ft}^{2} / \mathrm{d}$, which was the highest for all the wells, and had a composite water-level altitude of $707.7 \mathrm{ft}$ above NAVD 88 (table 3). Due to the relatively short open interval, only one flow zone was identified that was penetrated by the wellbore. The flow zone was from $338 \mathrm{ft}$ to the base of the wellbore at $354 \mathrm{ft}$ below land surface. The flow zone was associated with the vuggy beds of the lower carbonate rock unit, and included a pipe-like solution feature from 351 to $353 \mathrm{ft}$ below land surface (fig. 4).

The Golf Shack well had an estimated total transmissivity of $40 \mathrm{ft}^{2} / \mathrm{d}$ and composite water-level altitude of $717.8 \mathrm{ft}$ above NAVD 88 (table 3). Flow zones were penetrated by the wellbore at 124 and $219 \mathrm{ft}$ below land surface. The $124 \mathrm{ft}$ flow zone was in the upper carbonate rock unit and was associated with bedding partings. The zone had an estimated transmissivity of $2 \mathrm{ft}^{2} / \mathrm{d}$ and an estimated water-level altitude of $718.2 \mathrm{ft}$. The $219 \mathrm{ft}$ flow zone was in the carbonate rock and glauconitic sandstone unit and was associated with bedding partings. The zone had an estimated transmissivity value of $38 \mathrm{ft}^{2} / \mathrm{d}$ and an estimated water-level altitude of $717.7 \mathrm{ft}$.

The Community 1 well had an estimated total transmissivity of $185 \mathrm{ft}^{2} / \mathrm{d}$ and a composite water-level altitude of $696.7 \mathrm{ft}$ above NAVD 88 (table 3). Flow zones were penetrated by the wellbore at 200 and $283 \mathrm{ft}$ below land surface. The flow zones were in the carbonate rock and glauconitic sandstone unit (respectively) and were associated with bedding partings. The 200 and $283 \mathrm{ft}$ flow zones had estimated transmissivity values of 90 and $95 \mathrm{ft}^{2} / \mathrm{d}$, respectively.

The Community 2 well had an estimated total transmissivity of $280 \mathrm{ft}^{2} / \mathrm{d}$ and composite water-level altitude of $689.2 \mathrm{ft}$ above NAVD 88 (table 3). Flow zones were penetrated by the wellbore at 204, 295, 310, and 320 to $350 \mathrm{ft}$ below land surface. The 204, 295, and $310 \mathrm{ft}$ zones were in the carbonate rock and glauconitic sandstone unit and were associated with bedding partings. Those zones had estimated transmissivity values of 130,105 , and $25 \mathrm{ft}^{2} / \mathrm{d}$, respectively. The 320 to $350 \mathrm{ft}$ zone was in the lower carbonate rock unit and was associated with the vuggy beds of the lower carbonate rock unit. The flow zone had an estimated transmissivity of $20 \mathrm{ft}^{2} / \mathrm{d}$.

Pumping of the Casino 5 well at $80 \mathrm{gal} / \mathrm{min}$ resulted in increased downward flow in the Casino 3 well from the upper flow zones at 144, 198, and $247 \mathrm{ft}$ below land surface to the lower flow zone at 332 to $350 \mathrm{ft}$ below land surface (fig. 5). The measured and simulated increase in downward flow during this cross-well test indicated that the 332 to $350 \mathrm{ft}$ flow zone penetrated by the Casino 3 well was hydraulically connected to the 338 to $352 \mathrm{ft}$ flow zone penetrated by the Casino 5 well. 


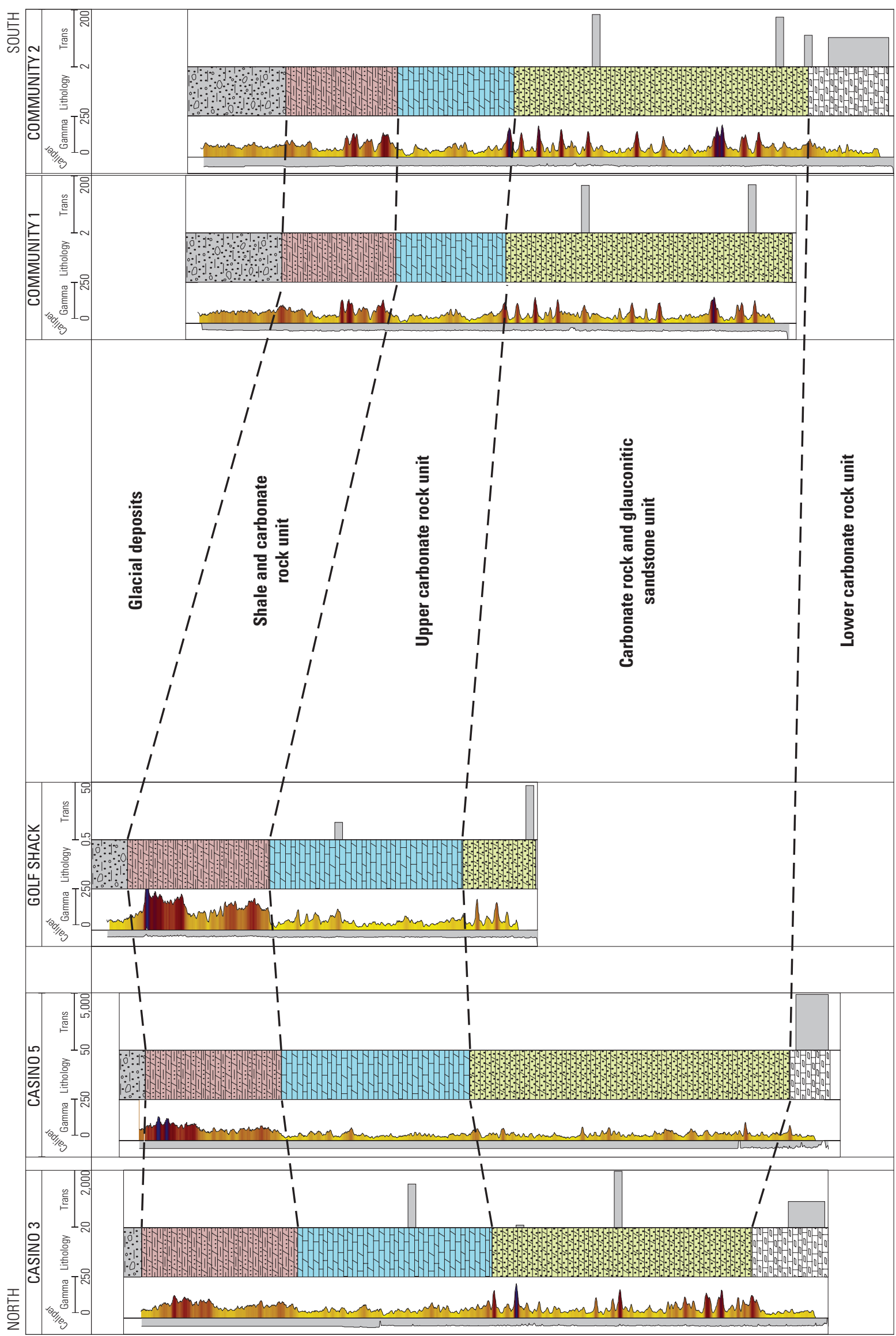



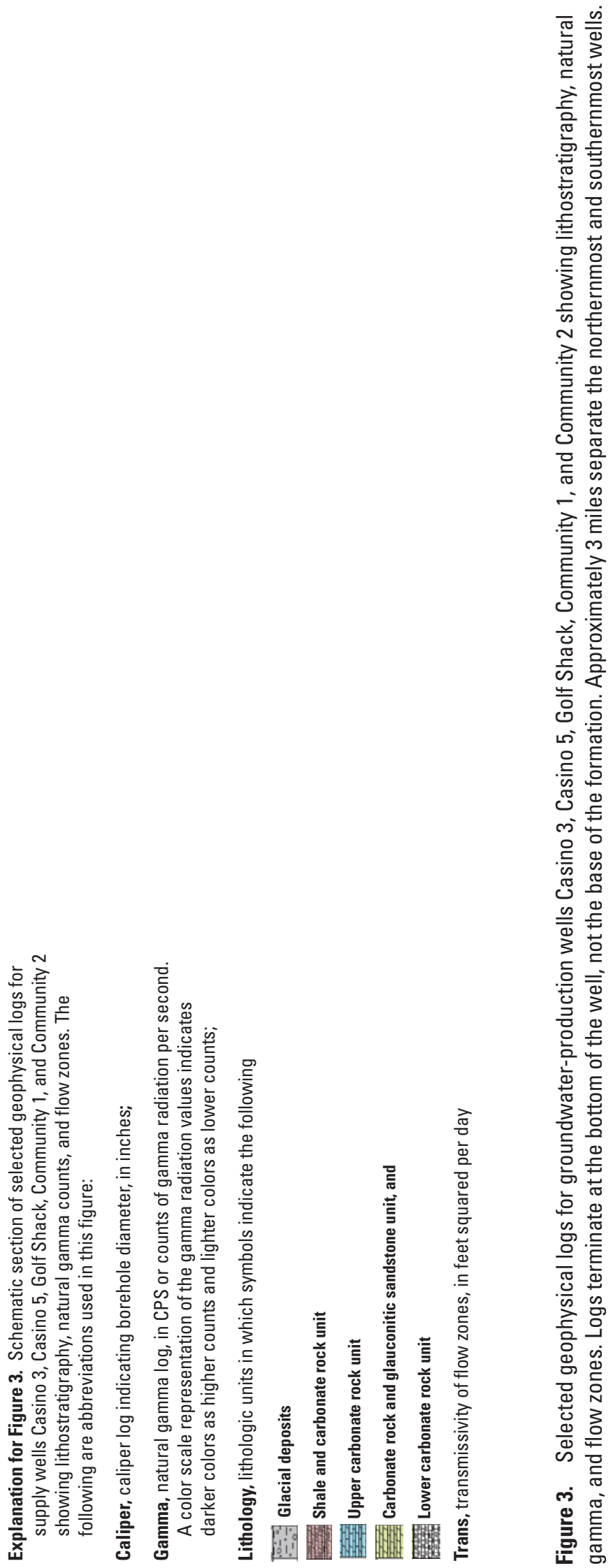
Depth,

in feet below land surface

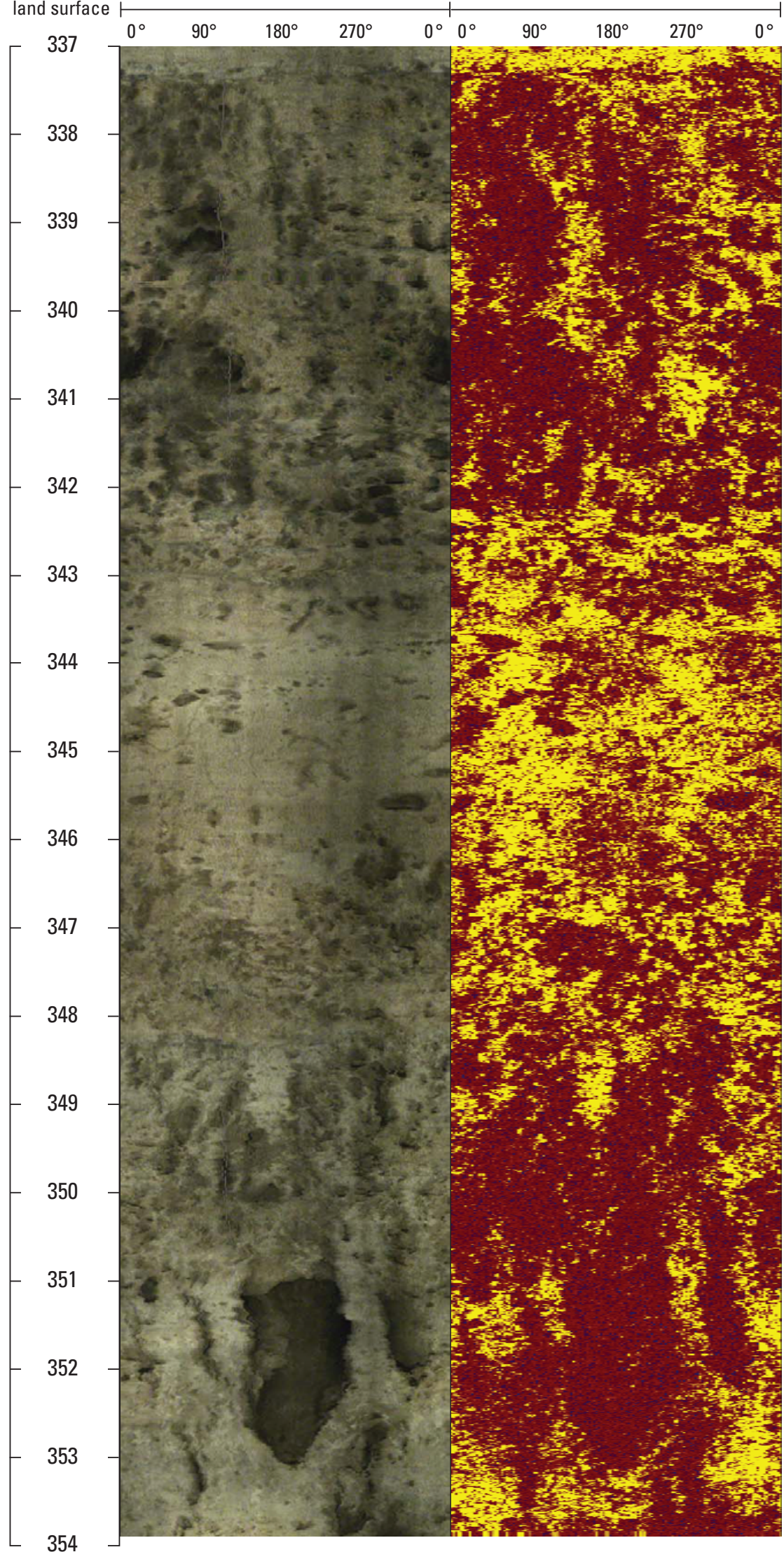

Figure 4. Optical televiewer (OTV) and acoustic televiewer (ATV) logs of the bottom 17 feet of the Casino 5 well showing vuggy beds in the lower carbonate rock unit. 
Table 3. Summary of distribution and hydraulic properties of the flow zones penetrated by each of five groundwater-production wells at Hannahville Indian Community, Menominee County, Michigan.

[mm/dd/yyyy, month-day-year; $\mathrm{ft}^{2} / \mathrm{d}$, foot squared per day; NAVD 88, North American Vertical Datum of 1988; -, minus sign in front of value indicates hydraulic head is lower than composite water level; +, plus sign in front of value indicates hydraulic head is higher than composite water level; NA, not applicable]

\begin{tabular}{|c|c|c|c|c|c|c|c|}
\hline $\begin{array}{l}\text { Flow zone, } \\
\text { in feet } \\
\text { below land } \\
\text { surface }\end{array}$ & $\begin{array}{c}\text { Date, } \\
\text { in } \mathrm{mm} / \mathrm{dd} / \mathrm{yyyy}\end{array}$ & $\begin{array}{l}\text { Trans- } \\
\text { missivity, } \\
\text { in } \mathrm{ft}^{2} / \mathrm{d}\end{array}$ & $\begin{array}{c}\text { Specific } \\
\text { capacity, } \\
\text { in gallons } \\
\text { per minute } \\
\text { per foot }\end{array}$ & $\begin{array}{l}\text { Drawdown } \\
\text { at quasi- } \\
\text { steady state, } \\
\text { in feet }\end{array}$ & $\begin{array}{c}\text { Composite } \\
\text { water-level } \\
\text { elevation, } \\
\text { in feet above } \\
\text { NAVD } 88\end{array}$ & $\begin{array}{c}\text { Estimated } \\
\text { hydraulic } \\
\text { head, } \\
\text { in feet }\end{array}$ & Lithology \\
\hline \multicolumn{8}{|c|}{ Casino 3} \\
\hline & 09/08/2012 & 3,570 & 12.6 & 0.50 & 708 & & \\
\hline 144 & & 675 & & & & -0.04 & Upper carbonate \\
\hline 198 & & 25 & & & & +3.00 & Carbonate-rock and glauconitic sandstone \\
\hline 247 & & 1,830 & & & & .00 & Carbonate-rock and glauconitic sandstone \\
\hline $332-350$ & & 1,040 & & & & -.04 & Lower carbonate \\
\hline \multicolumn{8}{|c|}{ Casino 5} \\
\hline $338-354$ & $09 / 12 / 2012$ & 4,280 & 16.5 & 5.46 & 707.7 & & Lower carbonate \\
\hline \multicolumn{8}{|c|}{ Golf shack } \\
\hline & $09 / 10 / 2012$ & 40 & 0.20 & 4.37 & 717.8 & & \\
\hline 124 & & 2 & & & & +0.44 & Upper carbonate \\
\hline 219 & & 38 & & & & -.12 & Carbonate-rock and glauconitic sandstone \\
\hline \multicolumn{8}{|c|}{ Community 1} \\
\hline & $09 / 11 / 2012$ & 185 & 0.70 & 4.68 & 696.7 & & \\
\hline 200 & & 90 & & & & NA & Carbonate-rock and glauconitic sandstone \\
\hline 283 & & 95 & & & & NA & Carbonate-rock and glauconitic sandstone \\
\hline \multicolumn{8}{|c|}{ Community 2} \\
\hline & 09/07/2012 & 280 & 1.10 & 5.35 & 689.2 & & \\
\hline 204 & & 130 & & & & NA & Carbonate-rock and glauconitic sandstone \\
\hline 295 & & 105 & & & & NA & Carbonate-rock and glauconitic sandstone \\
\hline 310 & & 25 & & & & NA & Carbonate-rock and glauconitic sandstone \\
\hline $320-350$ & & 20 & & & & NA & Lower carbonate \\
\hline
\end{tabular}




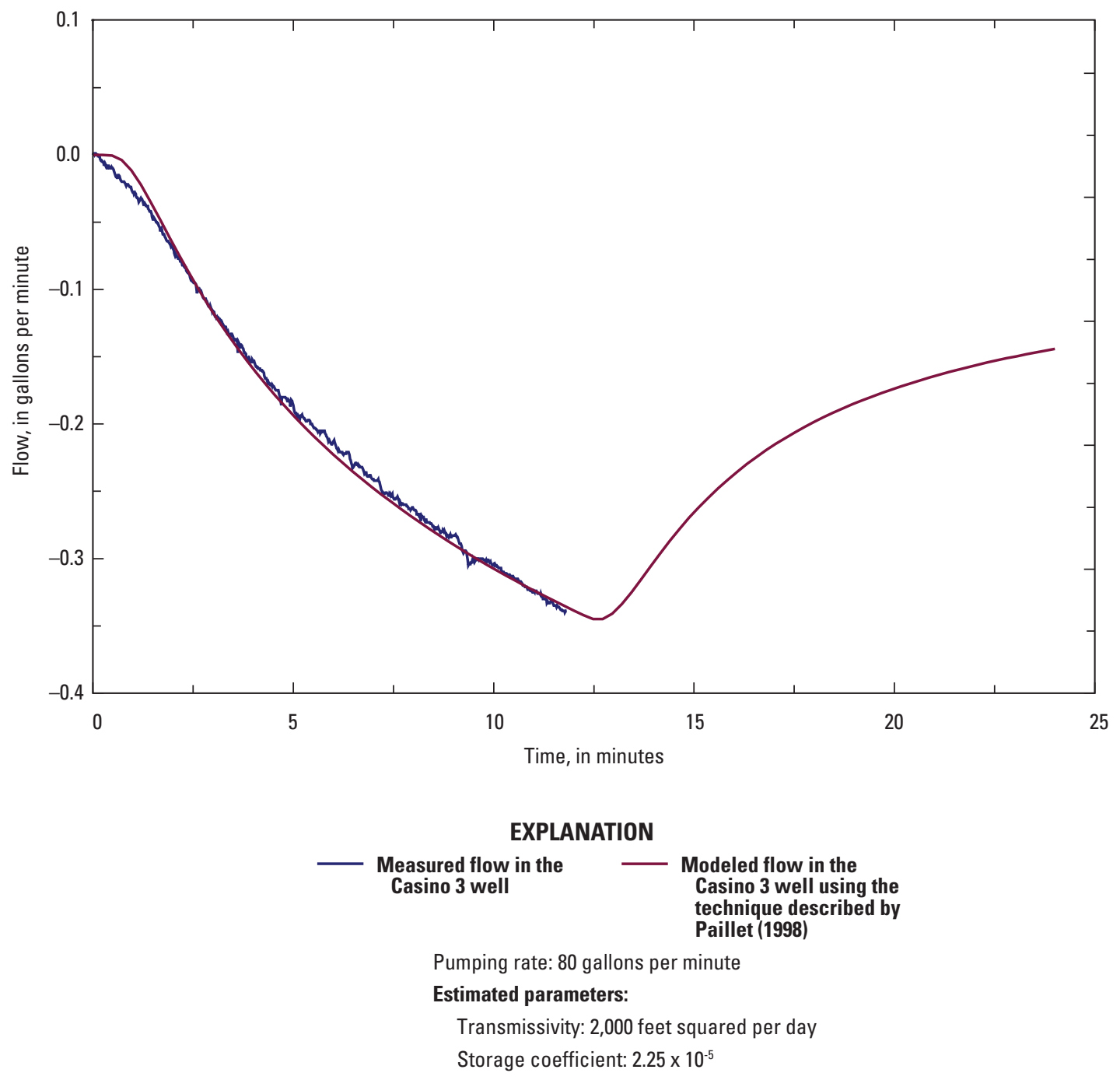

Figure 5. Measured change in flow in the Casino 3 well at 271 feet below land surface while the Casino 5 well is pumped at 80 gallons per minute, and model analysis of cross-flow data by use of the technique of Paillet (1998). 


\section{Summary and Conclusions}

Geophysical-logging and hydraulic-testing methods were used to gather data to characterize the lithostratigraphy, fractures, and hydraulic properties of the bedrock penetrated by five groundwater-production wells cased through the glacial drift and open to the bedrock within the Hannahville Indian Community in Michigan's Upper Peninsula. The geophysical logs included natural-gamma, electromagnetic-induction, wellbore-image, caliper, flow, fluid resistivity and temperature, and wellbore azimuth and tilt. Ambient flow, fluid resistivity, and temperature logs were collected under stabilized nonpumping water-level conditions and under constant-rate pumping. The total transmissivity of the open interval of the wells was estimated from specific capacity (pumping rate divided by quasi-steady-state drawdown) determined during hydraulic tests. The transmissivity and hydraulic head of each detected flow zone penetrated by the wells was estimated from the total transmissivity, quasi-steady-state drawdown, and ambientand stressed-condition flow logs. The hydraulic connection between the flow zones penetrated by two of the wells was characterized by cross-well flow testing.

The geophysical log analysis indicated that the five wells drilled through four distinct lithostratigraphic units - shale and carbonate rock unit, upper carbonate rock unit, carbonate rock and glauconitic sandstone unit, and lower carbonate rock unit. The shale and carbonate rock unit, upper carbonate rock unit, and carbonate rock and glauconitic sandstone unit was penetrated by all five wells. The top of the lower carbonate rock unit was penetrated by the following wells: Casino 3, Casino 5, and Community 2.

Most of the fractures penetrated by the wells appeared to be related to bedding partings. The carbonate rock and glauconitic sandstone unit had the highest fracture density, and the majority of the fractures were in the upper 50 feet (ft) of that unit.

Analyses of the geophysical logs and hydraulic tests indicated that the wells penetrated one to four flow zones that were associated with bedding partings and (or) solution features. The Casino 3 well penetrated flow zones at 144, 198,247 , and 332 to $350 \mathrm{ft}$ below land surface. The well had an estimated total transmissivity of 3,570 feet square per day $\left(\mathrm{ft}^{2} / \mathrm{d}\right)$. The estimated transmissivity of the individual flow zones penetrated by the well ranged from 25 to $1,830 \mathrm{ft}^{2} / \mathrm{d}$. The Casino 5 well penetrated one flow zone from 338 to $354 \mathrm{ft}$ below land surface with an estimated transmissivity of $4,280 \mathrm{ft}^{2} / \mathrm{d}$. The 332 to $350 \mathrm{ft}$ flow zone penetrated by the Casino 3 and the 338 to $352 \mathrm{ft}$ flow zone penetrated by the Casino 5 were hydraulically connected. The Golf Shack well penetrated flow zones at 124 and $219 \mathrm{ft}$ below land surface with estimated transmissivity values of 2 and $38 \mathrm{ft}^{2} / \mathrm{d}$, respectively. The Community 1 well penetrated flow zones at 200 and $283 \mathrm{ft}$ below land surface with estimated transmissivity values of 90 and $95 \mathrm{ft}^{2} / \mathrm{d}$, respectively. The Community 2 well penetrated flow zones at 204, 295, 310 and from 320 to $350 \mathrm{ft}$ below land surface. The well had an estimated total transmissivity of $280 \mathrm{ft}^{2} / \mathrm{d}$. The estimated transmissivity of the individual flow zones ranged from 20 to $130 \mathrm{ft}^{2} / \mathrm{d}$.

\section{References Cited}

Bradbury, K.R., and Rothschild, E.R., 1985, A computerized technique for estimating the hydraulic conductivity of aquifers from specific capacity data: Ground Water, v. 23, no. 2, p. 240-246.

Collier, H.A., 1993, Borehole geophysical techniques for determining the water quality and reservoir parameters of fresh and saline water aquifers in Texas-Volume I of II: Austin, Tex., Texas Water Development Board Report 343, accessed June 19, 2013, at http://www.twdb.state.tx.us/publications/reports/numbered_reports/doc/R343/report343.asp.

Day-Lewis, F.D., Johnson, C.D., Paillet, F.L., and Halford, K.J., 2011, A computer program for flow-log analysis of single holes (FLASH): Ground Water, v. 49, no. 6, p. 926-931.

Keys, W.S., 1990, Borehole geophysics applied to groundwater investigations: U.S. Geological Survey Techniques of Water-Resources Investigations, book 2, chap. E2, p. 150. (Also available at http://pubs.usgs.gov/twri/twri2-e2/).

Olcott, P.G., 1992, Ground Water Atlas of the United StatesSegment 9, Iowa, Michigan, Minnesota, Wisconsin: U.S. Geological Survey Hydrologic Atlas 730-J, 31 p.

Paillet, F.L., 1998, Flow modeling and permeability estimation using borehole flow logs in heterogeneous fractured formations: Water Resources Research, v. 34, no. 5, p. 997-1010.

Rider, Malcolm, and Kennedy, Martin, 2011, The geological interpretation of well logs ( $3 \mathrm{~d}$ ed.): Glasgow, Rider-French Consulting Limited, ISBN 978-0-9541906-8-2, 432 p.

Sloan, E., 1997, Wellhead protection program-Hannahville Indian Community, Wilson, Michigan: MJ Environmental Consultants, $44 \mathrm{p}$.

Theis, C.V., Brown, R.H., and Myer, R.R., 1964, Estimating the transmissivity of aquifers from the specific capacity of wells, in Bentall, Ray, comp., Methods of determining permeability, transmissivity and drawdown: U.S. Geological Survey Water-Supply Paper 1536-I, p. 331-340.

Thiem, G., 1906, Hydrologische Methoden: Leipzig, Gebhardt, 56 p.

U.S. Census Bureau, 2012, State \& County QuickFactsMenominee County, Michigan, accessed December 5, 2012, at http://quickfacts.census.gov/qfd/states/26/26109.html. 
U.S. Geological Survey, 2000, Groundwater informationNational aquifer code reference list - Cambrian-Ordovician aquifer system, accessed June 19, 2013, at http://water.usgs. gov/ogw/NatlAqCode-reflist.html.

U.S. Geological Survey, 2003, Principal aquifers of the 48 conterminous United States, Hawaii, Puerto Rico, and the U.S. Virgin Islands, available at http://nationalatlas.gov/ mld/aquifrp.html.

Vanlier, K.E., 1963, Ground-water in Menominee County: Michigan Geological Survey Water Investigation 2, 42 p., accessed February 5, 2013, at http://www.michigan.gov/ documents/deq/WI_02opt_309839_7.pdf.

Williams, J.H., and Paillet, F.L., 2002, Using flowmeter pulse tests to define hydraulic connections in the subsurfaceA fractured shale example: Journal of Hydrology, v. 265, nos. $1-4$, p. $100-117$.

Young, S.C., and Pearson, H.S., 1995, The electromagnetic borehole flowmeter-Description and application: Groundwater Monitoring \& Remediation, v. 15, no. 4, p. 138-147. 


\section{Appendix 1. Composites of the Geophysical Logs and Their Analysis}

Figure 1-1. Composite of geophysical logs for the Casino 3 well ..............................................21

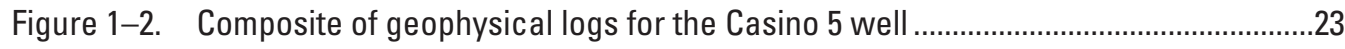

Figure 1-3. Composite of geophysical logs for the Golf Shack well ............................................25

Figure 1-4. Composite of geophysical logs for the Community 1 well .......................................27

Figure 1-5. Composite of geophysical logs for the Community 2 well ........................................29 
Explanation for figures 1-1 to 1-5. Composite of geophysical logs for groundwaterproduction wells: (fig. 1-1) Casino 3 well; (fig. 1-2) Casino 5 well; (fig. 1-3) Golf Shack well; (fig. 1-4) Community 1 well; and (fig. 1-5) Community 2 well. All depths are in feet below land surface, as indicated on left-most vertical axis. The following are abbreviations used in this figure:

Gamma, natural gamma log, in CPS or counts of gamma radiation per second. A color scale representation of the gamma radiation values indicates darker colors as higher counts and lighter colors as lower counts;

Litho, lithologic units in which symbols indicate the following

Glacial deposits

Shale and carbonate rock unit

Upper carbonate rock unit

Carbonate rock and glauconitic sandstone unit, and

Lower carbonate rock unit

Cond, formation conductivity, in $\mathrm{mS} / \mathrm{m}$ or millisiemens per meter (one millisiemen is equivalent to one millimho);

OTV, optical televiewer image, taken relative to MN-Deg (magnetic north);

Bed, tadpole points represent bedding strike and dip, in MN-Deg (or degrees relative to magnetic north) where the tadpole tail indicates the direction of dip relative to magnetic north;

ATV, acoustic televiewer log, where the acoustic image indicates possible voids as darker colors and solid rock with fewer or no voids as lighter colors;

Frac, in which tadpole points represent direction of fracture dip and fracture dip angle. The points indicate the angle of the dip in degrees. Hydraulically active fractures are plotted as blue symbols. Fractures that are not hydraulically active are plotted as gray symbols. The tadpole tail from each symbol indicates the direction of dip relative to magnetic north;

Caliper, indicating borehole diameter, in inches;

Flow amb, ambient wellbore flow, in gal/min (gallons per minute);

Flow pmp, pumping wellbore flow, in $\mathrm{gal} / \mathrm{min}$;

Trans, transmissivity of flow zones, in feet squared per day;

WL ele, elevation of flow zone water level, in feet above the NAVD 88 vertical datum;

FI res amb, ambient fluid resistivity in $0 \mathrm{hm}-\mathrm{m}$ (Ohm meters);

FI res pmp, $t=\mathbf{X X}$, in which $t=X X$ is the elapsed time in minutes from starting pump, and pumping fluid resistivity is in $0 \mathrm{hm}-\mathrm{m}$;

Temp amb, ambient fluid temperature in Deg $F$ (degrees Fahrenheit);

Temp pmp, $t=X X$, where $t=X X$ is the elapsed time in minutes from starting pump, and pumping fluid temperature is in Deg F;

Azi MN, is the wellbore deviation from magnetic north, in Deg (degrees); and

Tilt, is the wellbore deviation from vertical in Deg 
(Headnote for header information of borehole geophysical logs in Appendix 1, Figures 1-1 to 1-5)

[Abbreviations used in borehole geophysical logs: E, English; USGS, U.S. Geological Survey; Date format in month/day/year; MI, Michigan; LS, land surface, NAVD 88, North Americ an Vertical Datum; NY, New York; IN, Indiana; MN, magnetic north; W, west; gal/min, gallons per minute; time format in hour:minute; $\mathrm{ft}$, feet; ZZ, software code indicating presentation of multiple logs on a figure; SN\#, serial number, $\mathrm{mS} / \mathrm{m}$, millisiemen per meter; CPS, counts per second; deg, degrees; cal, calibration; EM-fluid,amb, electromagnetic fluid resistivity log, ambient; pmp, pumped; Deg F, degrees Fahrenheit; Ohm-M, ohm-meters; EM flow,amb, ALS, above land surface] 


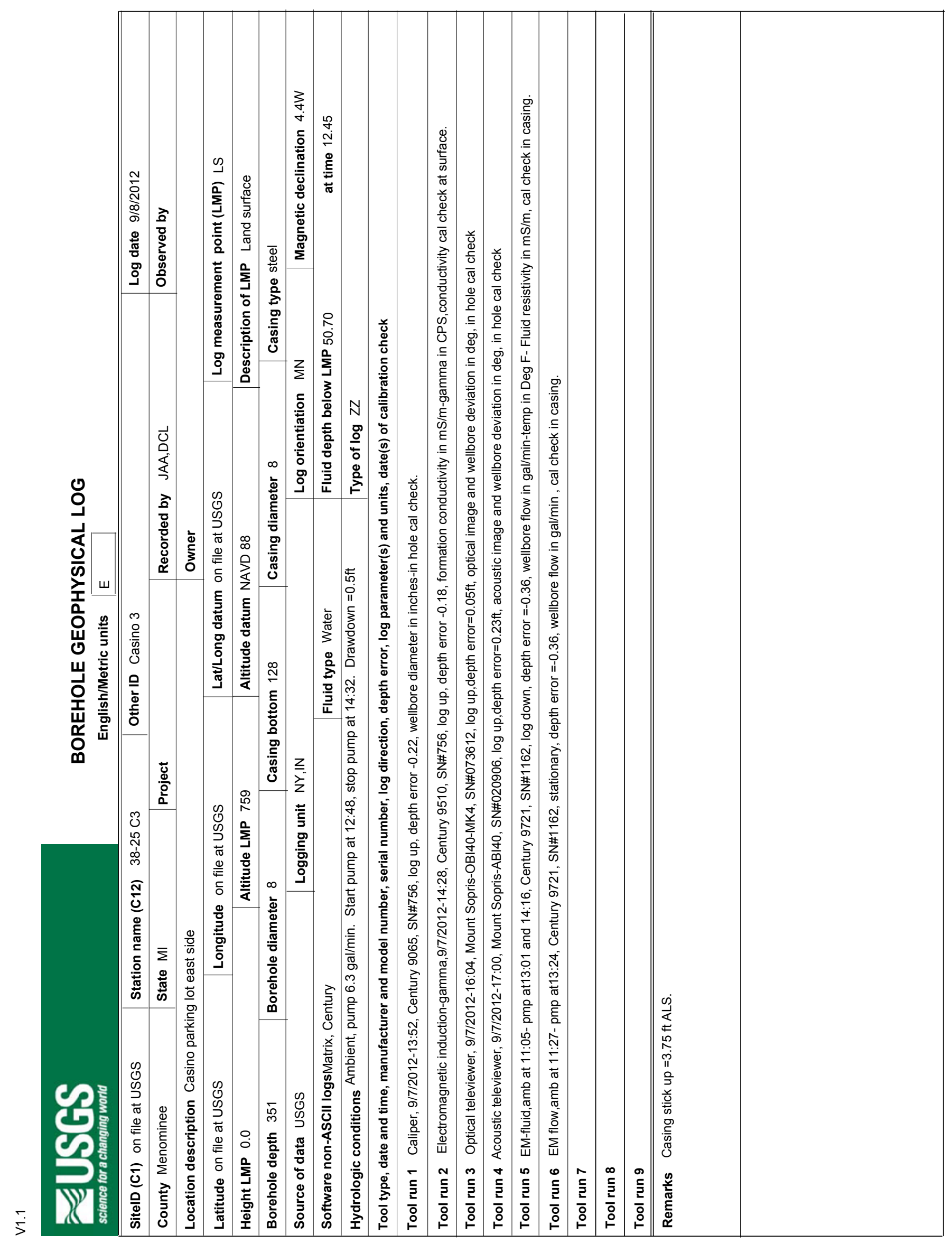




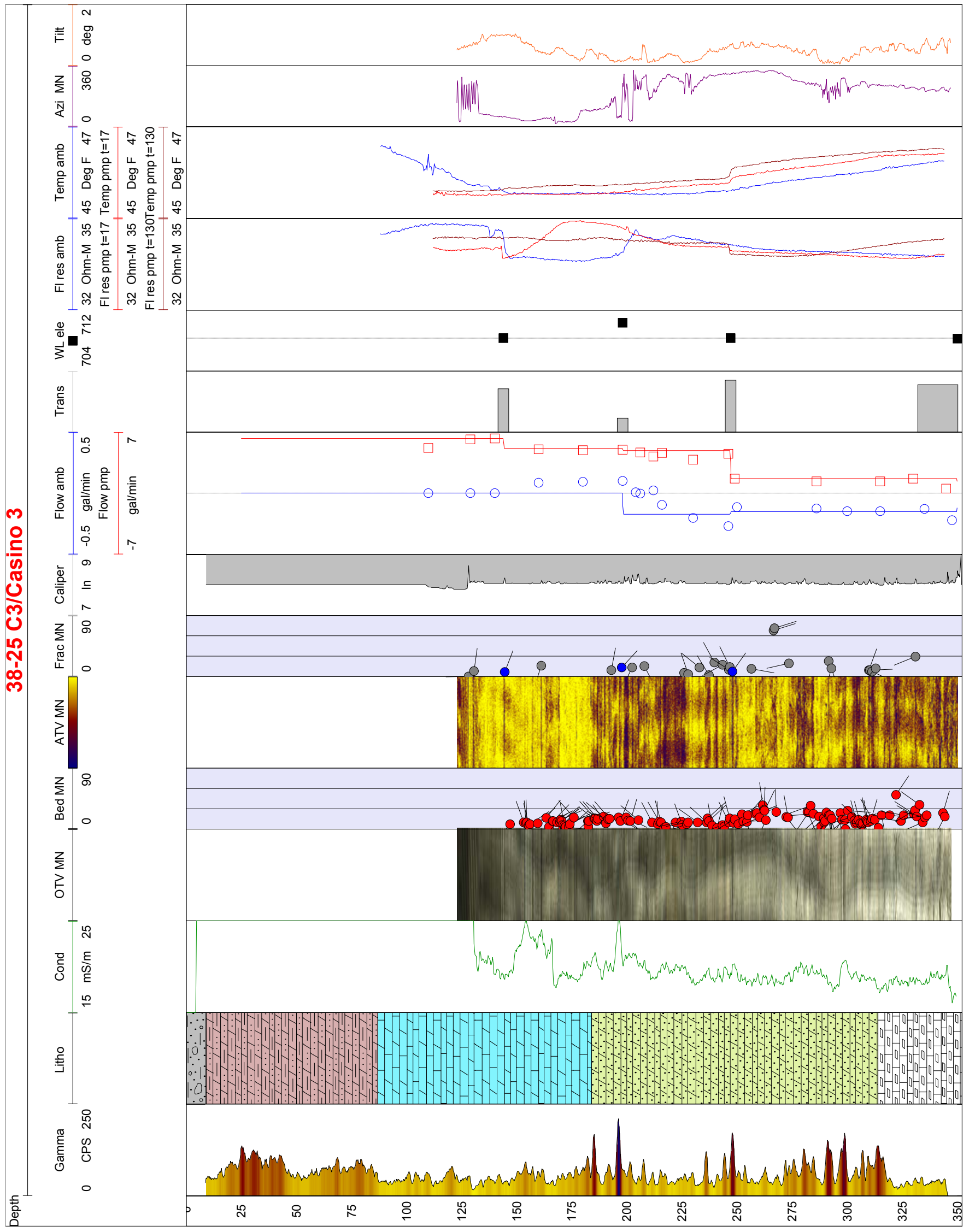

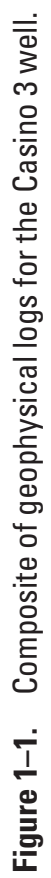




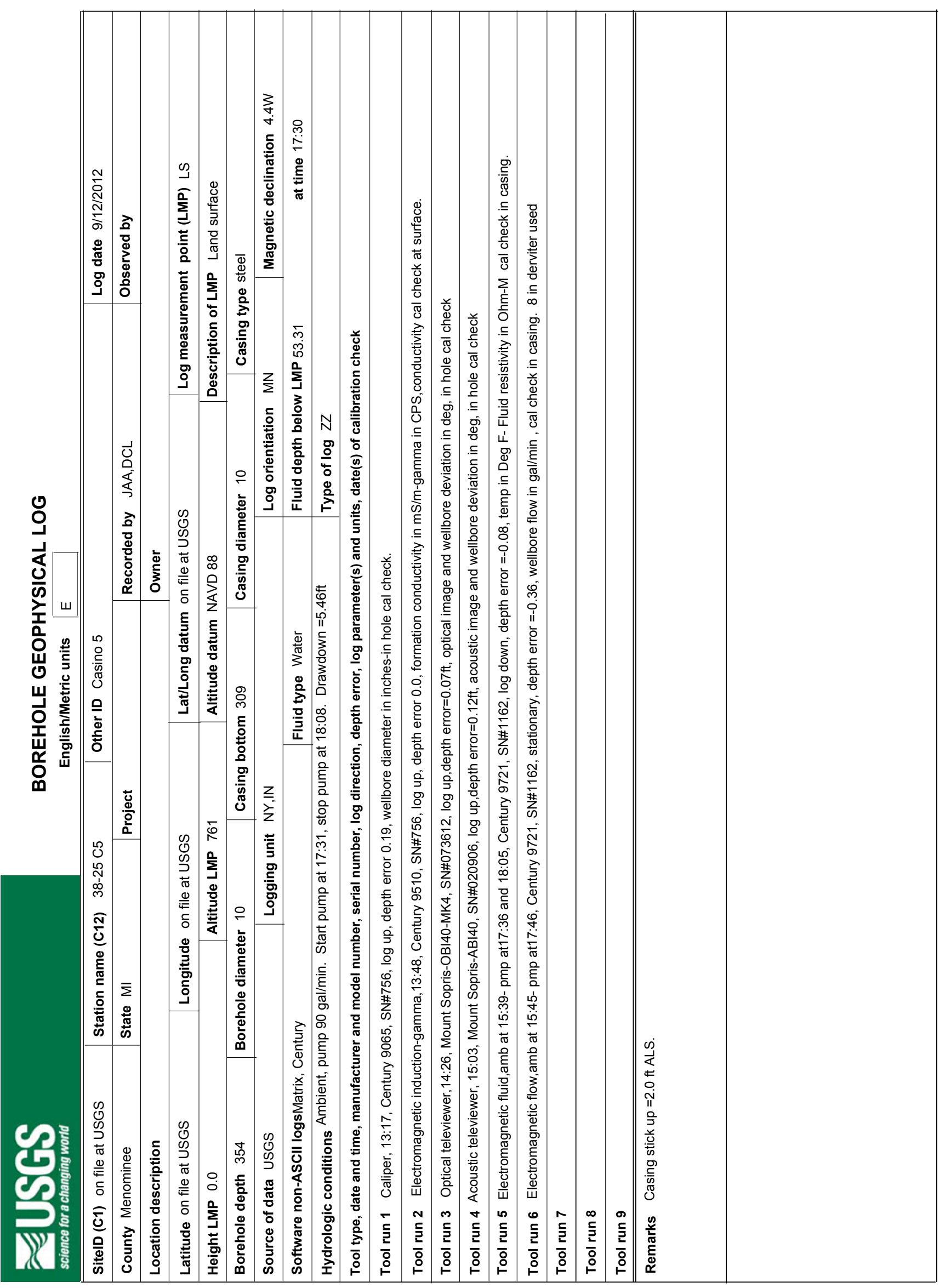




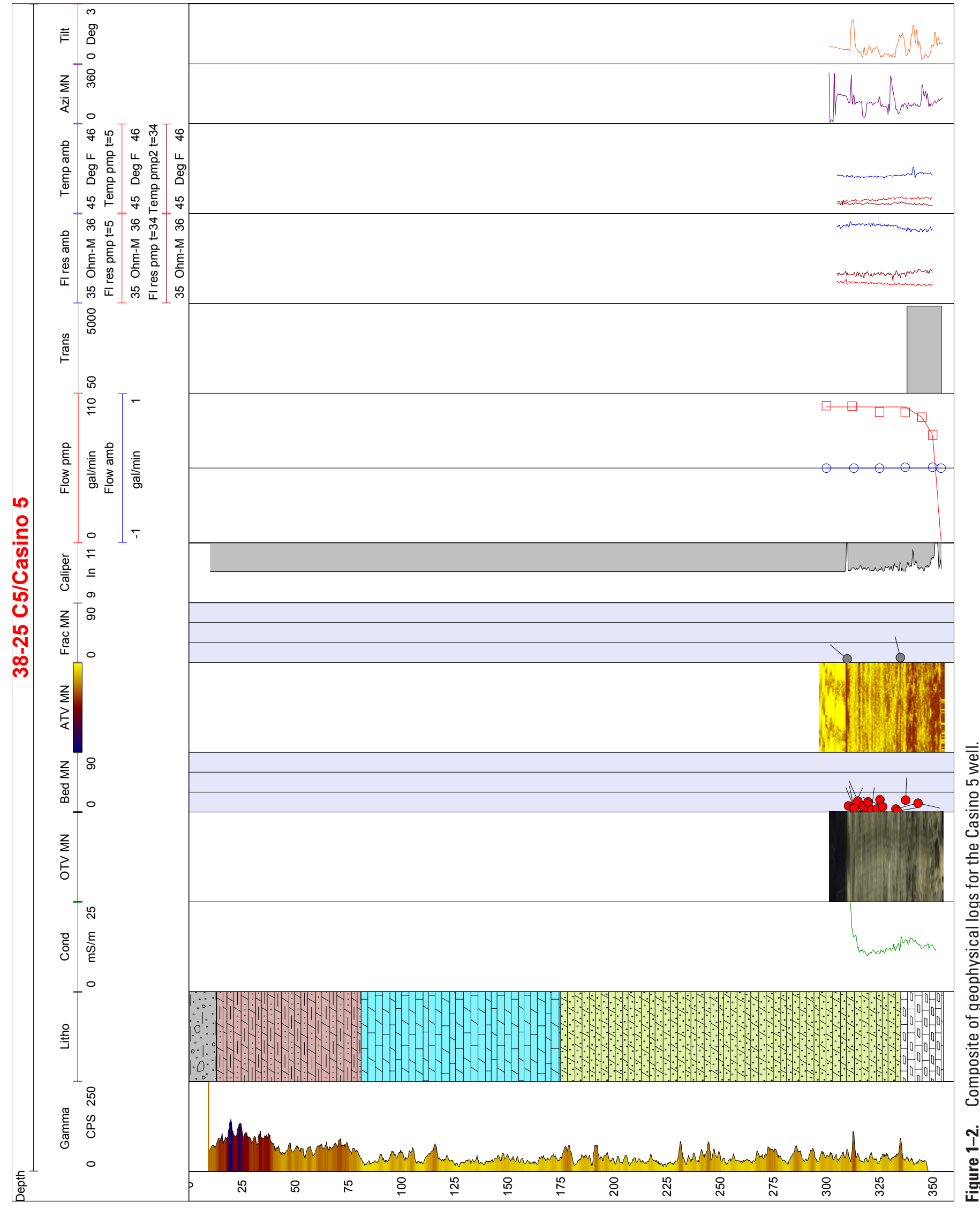




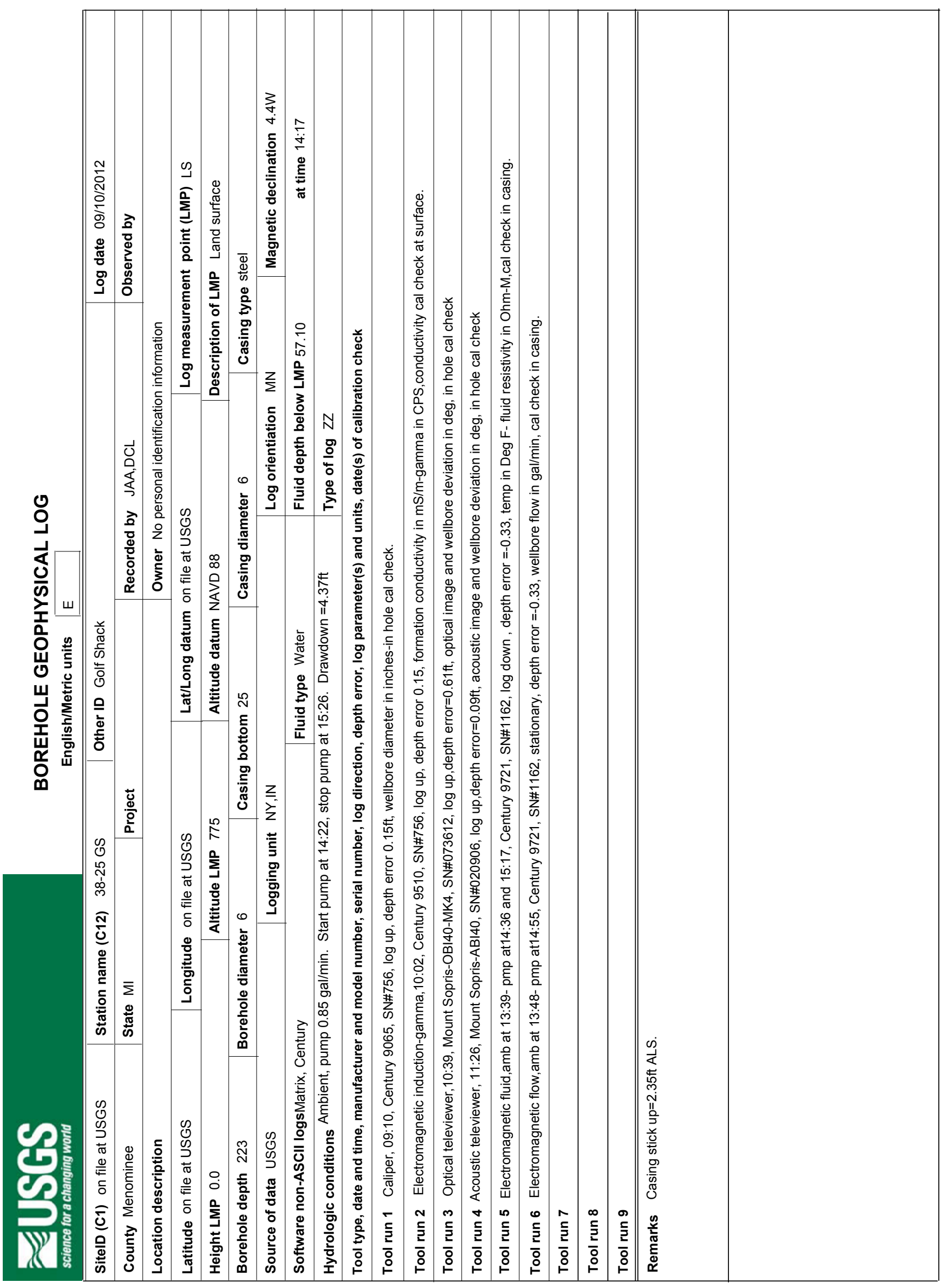




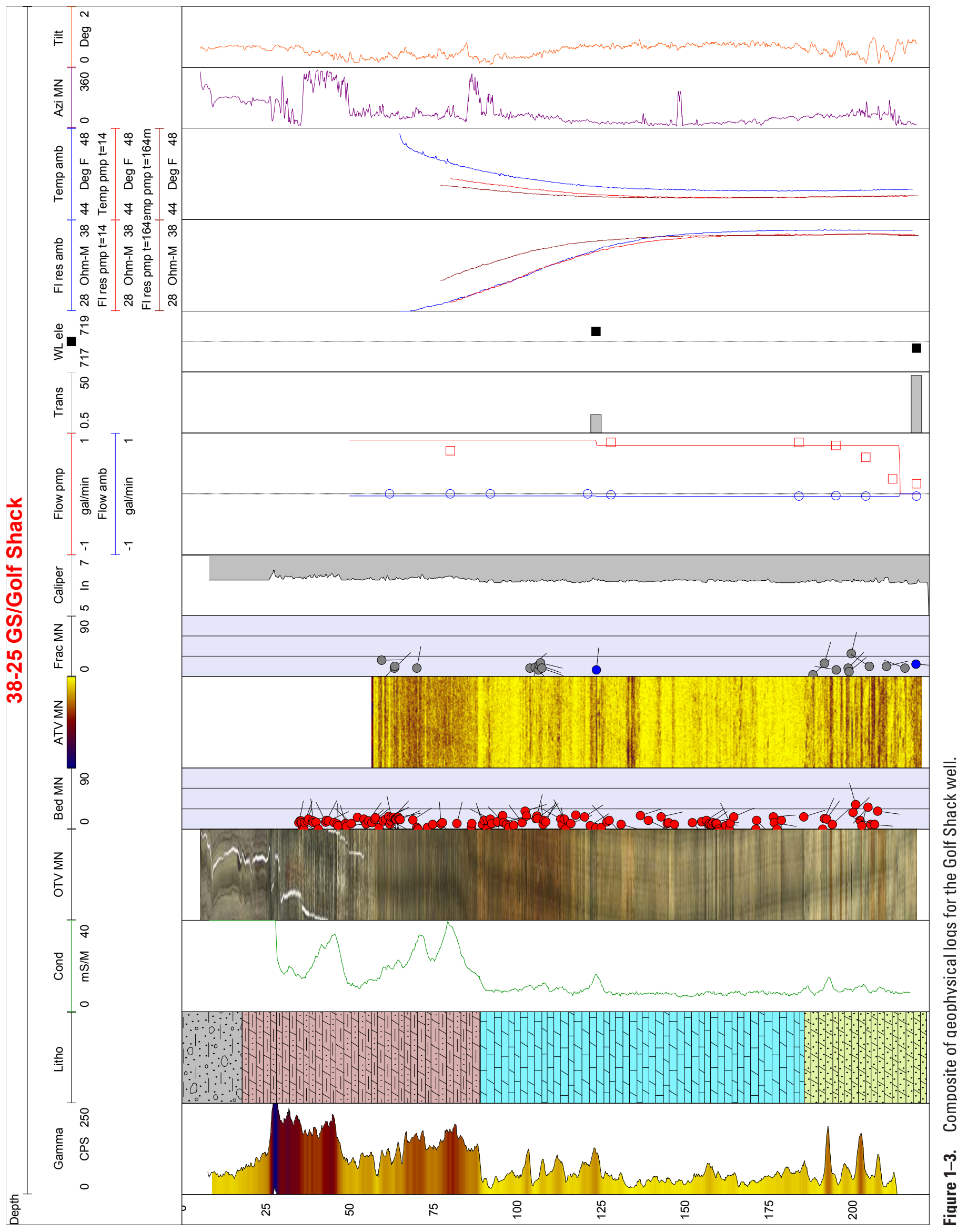




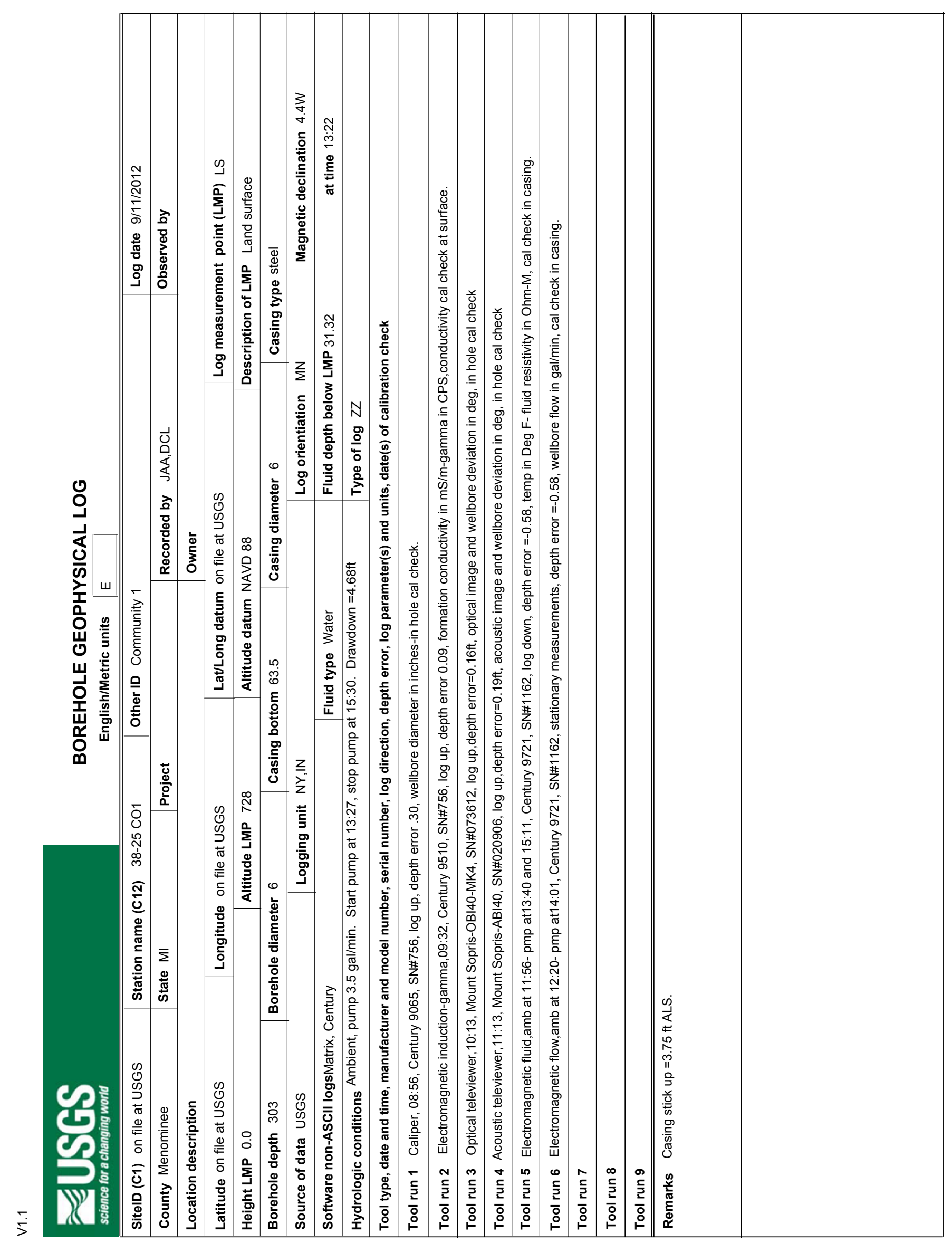




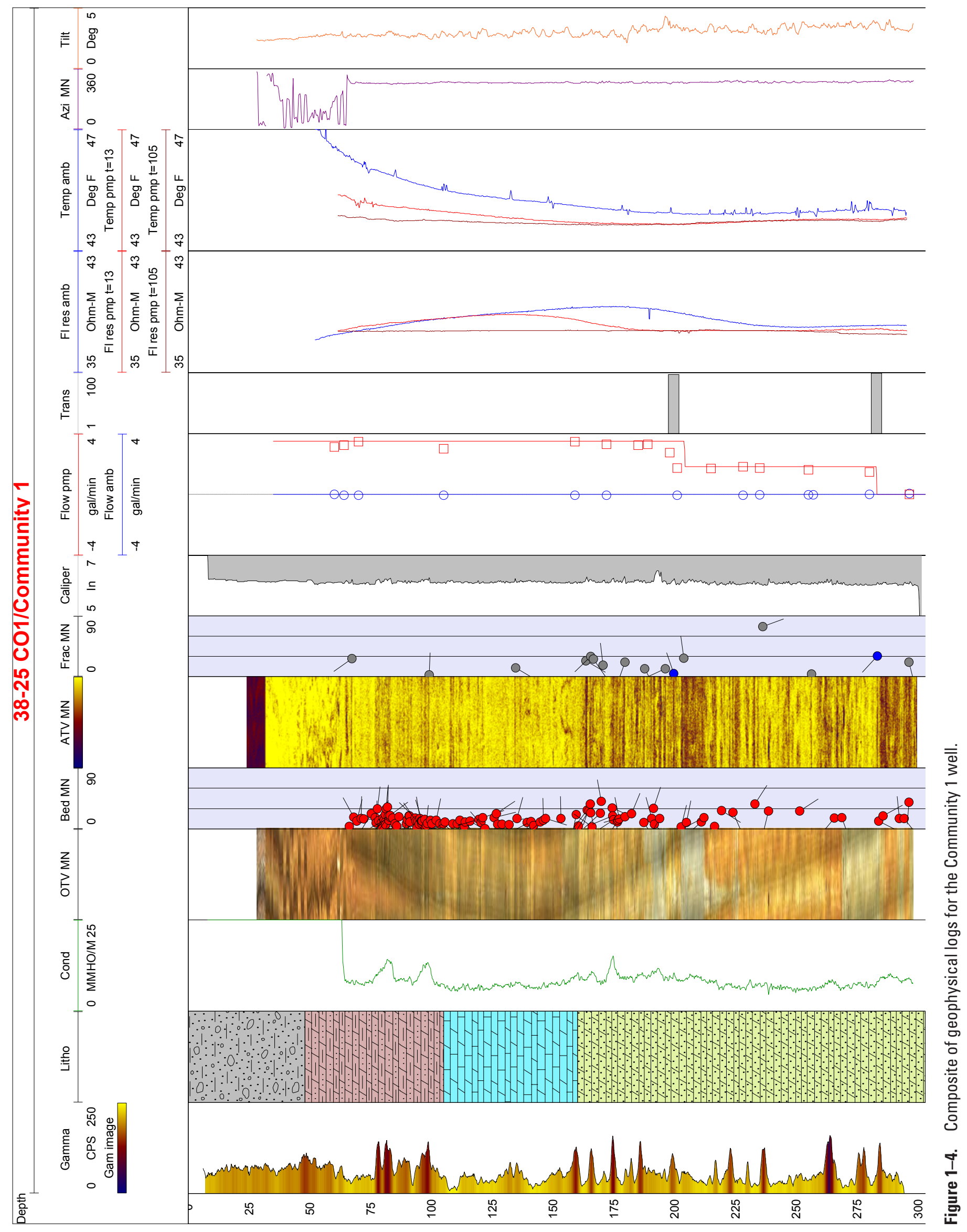




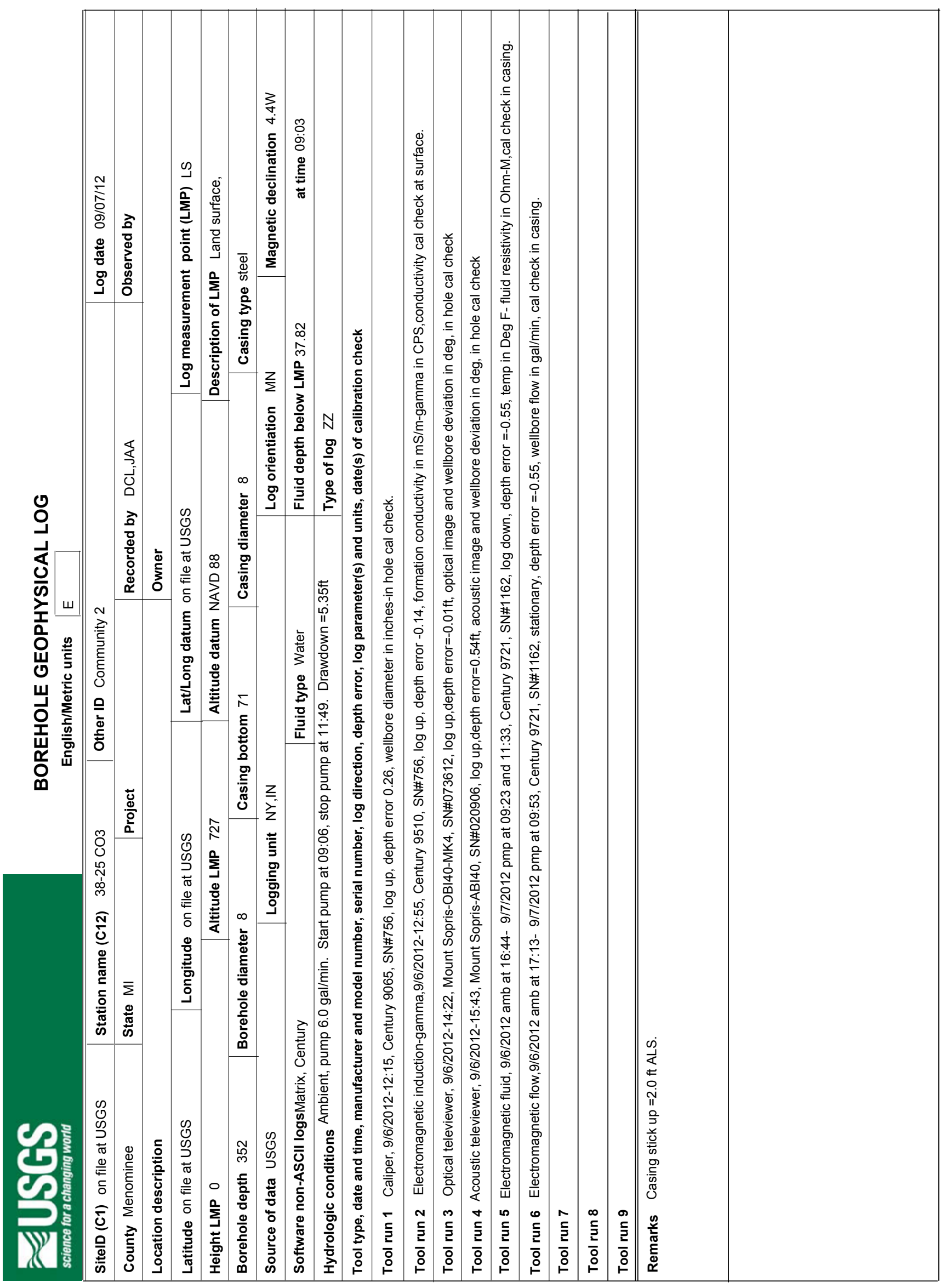




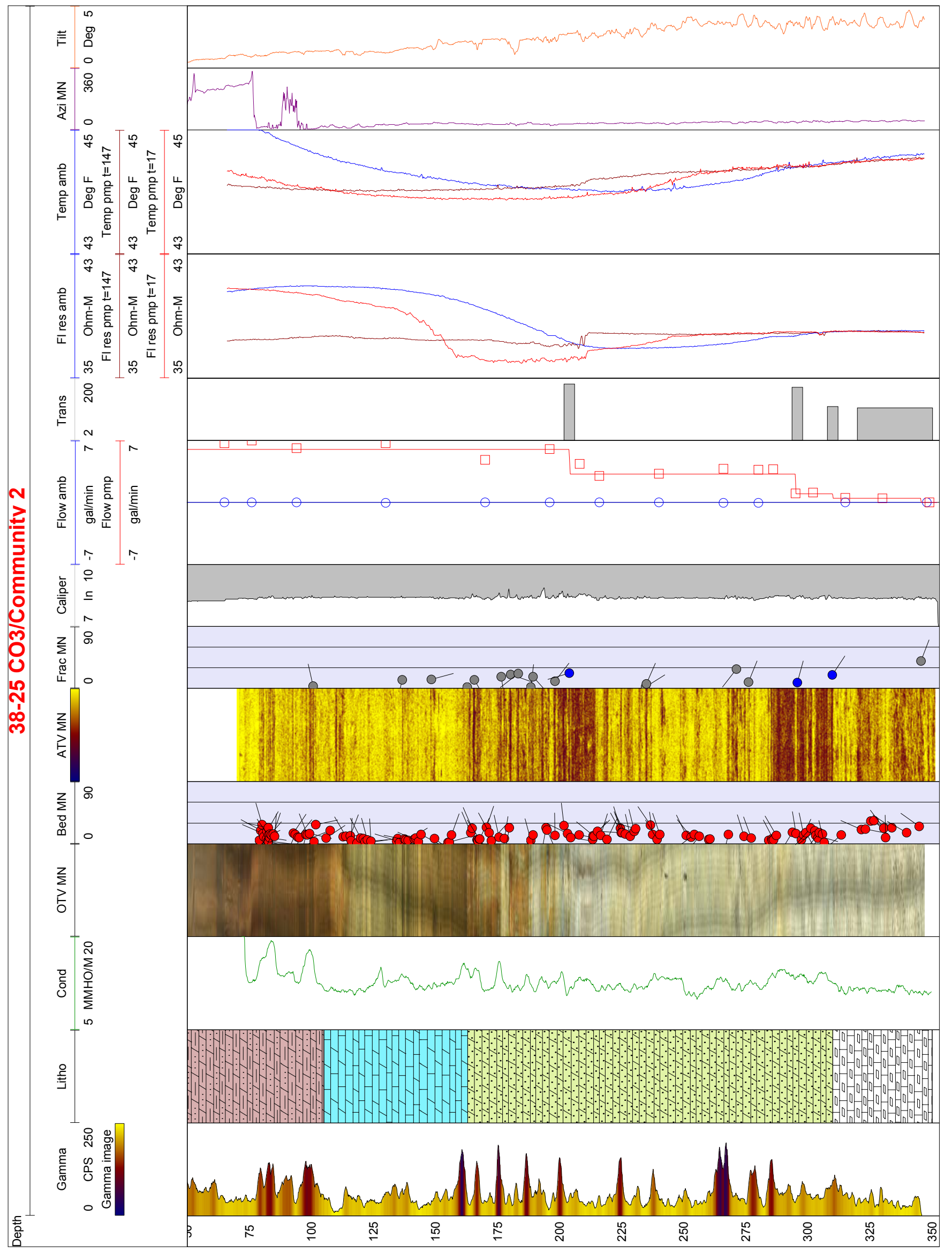

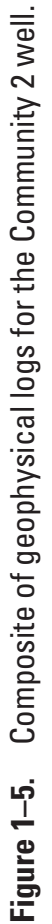



Prepared by the Columbus and Pembroke Publishing Service Centers

For additional information contact:

Director

U.S. Geological Survey

Michigan Water Science Center

6520 Mercantile Way, Suite 5

Lansing, MI 48911-5991

or visit our Web site at:

http://mi.water.usgs.gov/ 
